\title{
GAS TURBINE REHEAT USING IN-SITU COMBUSTION
}

\author{
Topical Report: \\ Task 2 - Combustion and Emissions \\ Cooperative Agreement No. DE-FC26-00NT40913 \\ April 30, 2004 \\ by \\ D.M. Bachovchin \\ T.E. Lippert \\ Siemens Westinghouse Power Corporation \\ 4400 Alafaya Trail \\ Orlando, FL 32826 \\ Prepared for \\ U.S. Department of Energy \\ National Energy Technology Laboratory \\ 3610 Collins Ferry Road \\ P. O. Box 880 \\ Morgantown, WV 26507-0880 \\ Charles Alsup — DOE/NETL Project Manager
}




\section{DISCLAIMER}

This report was prepared as an account of work sponsored by the United States Government. Neither the United States nor the United States Department of Energy, nor any of their employees, makes any warranty, expressed or implied, or assumes any legal liability or responsibility for the accuracy, completeness, or usefulness of any information, apparatus, product, or process disclosed, or represents that its use would not infringe privately owned rights. Reference herein to any specific commercial product, process, or service by trade name, mark, manufacturer, or otherwise, does not necessarily constitute or imply its endorsement, recommendation, or favoring by the United States Government or any agency thereof. The views and opinions of authors expressed herein do not necessarily state or reflect those of the United States Government or any agency thereof. 


\begin{abstract}
Siemens Westinghouse Power Corporation (SWPC) is developing in-situ reheat (fuel injection via airfoil injection) as a means for increasing cycle efficiency and power output, with possibly reduced emissions. This report discusses detailed chemical kinetics (using CHEMKIN and GRI 3.0 database) of fuel injection. Other program tasks are CFD modeling (by Texas A\&M) of airfoil injection and its effects on blade aerodynamics and turbine performance; and high pressure, high temperature combustion rig testing. In the chemical kinetics studies, models of diffusion flame, wake flame (using small flameholders), and dispersed combustion are used to project emissions. The best location for injection is at the trailing edge of the inlet guide vane, without flameholding, Combustion is incomplete at trailing edges of subsequent vanes, unless small flameholders are used. These conclusions agree with CFD simple kinetics projections.
\end{abstract}




\section{EXECUTIVE SUMMARY}

Gas turbine reheat is a well-known technique for increasing the power output of gas turbine, as well as the efficiency in combined cycle operation with higher heat recovery inlet temperatures. The technique also could allow development of an advanced high efficiency turbine with an additional stage, but without a higher inlet temperature. A novel reheat approach, with fuel added via internal passages in turbine airfoils, has been proposed [1]. This avoids the bulky and possible high-NOx discrete reheat combustors used in traditional approaches. The key questions regarding this approach are whether there is sufficient residence time at high temperature for fuel burnout, and whether increased emissions of NOx and $\mathrm{CO}$ result. This project examines the chemical kinetics basis of these questions.

In the present task detailed chemical kinetics models were used to evaluate injection reheat combustion. Models used included a Siemens Westinghouse diffusion flame model, the set of CHEMKIN gas-phase kinetics equation solvers, and the GRI 3.0 detailed kinetics data base. These modules are called by a reheat-specific main program, which also provides them with data, including gas path conditions that change with distance through the turbine.

Conceptually, injection could occur in either of two ways: 1) direct injection via holes in airfoil trailing edges; or 2) injection at the downstream faces of small bluff bodies placed at these edges. In the former case, combustion could occur as a diffusion flame at the hole, as a plume or streak following this zone, or as a substantially mixed out homogeneous region downstream. In the latter case, combustion could occur as a lower temperature, well-mixed, recirculating flame in the wake of the bluff body, followed by burnout in the same sequence of diffusion flame, streak, and mixed out.

The results were as follows. In the case of a conventional four-stage engine, vane 1 trailing edge injection can be achieved with complete burnout without a flameholder. However, there are projected NOx and $\mathrm{CO}$ penalties of about 10 ppmv each. For vane 2 injection a flameholder is necessary, although the CO survival is expected to be larger, on the order of 50 ppmv. In the case of an advanced five-stage engine, injection at vane 2 (same size and conditions, except temperature, as vane 1 of a 4-stage engine) should be with a flameholder to minimize $\mathrm{CO}$, keeping NOx and $\mathrm{CO}$ increases at about 20 and 10 ppmv respectively. 


\section{TABLE OF CONTENTS}

1. INTRODUCTION AND BACKGROUND …............................................ 1

2. PRELIMINARY NON-FLAMEHOLDING ANALYSIS .............................. 3

3. NON-FLAMEHOLDING DESIGN CONCEPT ….................................. 5

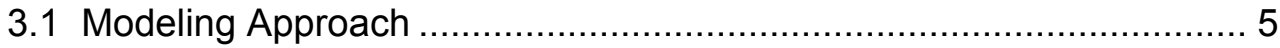

3.1.1 Calling Module.............................................................. 5

3.1.2 Diffusion Flame Model......................................................... 6

3.1.3 Empirical Factors ............................................................ 9

3.2 Fit to Experimental Data............................................................... 9

3.3 Parametric Study Results........................................................... 12

3.3.1 Four-Stage Turbine, Vane 1 Injection .................................... 13

3.3.2 Four-Stage Turbine, Vane 2 Injection .................................... 17

3.3.3 Five-Stage Turbine, Vane 2 Injection .................................... 18

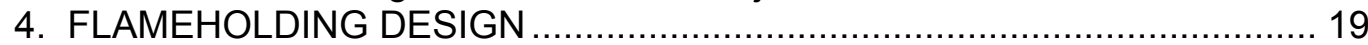

4.1 Modeling Approach ................................................................... 19

4.2 Parametric Study Results............................................................. 20

4.2.1 Four-Stage Turbine, Vane 1 Injection ................................... 20

4.2.2 Four-Stage Turbine, Vane 2 Injection ................................... 22

4.2.3 Five-Stage Turbine, Vane 2 Injection ....................................... 22

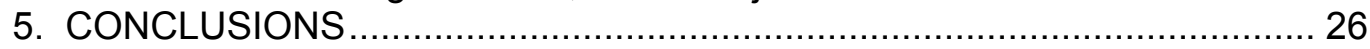

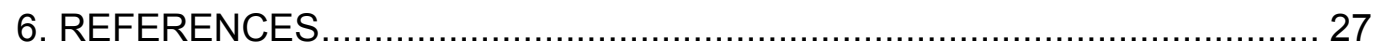

Table 1 - Test Conditions ......................................................................... 11

Table 2 - Vane 1 Trailing Edge Reheat, Fuel for 150 C Boost ........................ 14

Table 3 - Vane 1 Trailing Edge Reheat, Fuel for 300 C Boost ....................... 17

Table 4 - Vane 2 Trailing Edge Reheat, Fuel for 75 C Boost ......................... 17

Table 5 - Vane 2 Trailing Edge Reheat for a 5-Stage Turbine ....................... 18

Table 6 - Vane 1 Trailing Edge with Flameholding...................................... 21

Table 7 - Vane 1 Trailing Edge with Flameholding - Increased Fuel ................ 22

Table 8 - Vane 2 Trailing Edge with Flameholding....................................... 23

Table 9 - Vane 2 Trailing Edge Injection after Vane 1 Trailing Edge ............... 24

Table 10 - Vane 2 Trailing Edge Injection for a 5-Stage Turbine ..................... 25

Figure 1a - Vane 1 Injection Kinetics............................................................. 3

Figure 1b - Vane 1 Injection Kinetics......................................................... 4

Figure 2 - Blade Path Temperatures and NOx with 2-Stage Reheat ............... 4

Figure 3 - Experimental Apparatus............................................................ 10

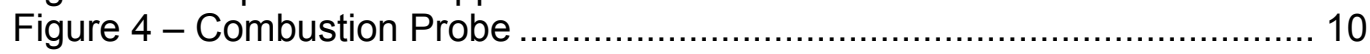

Figure 5 - Carbon Conversion - Model vs. Data ........................................... 12

Figure 6 - Projected NOx Emissions - Vane 1 TE Reheat............................. 15

Figure 7 - Projected CO Emissions - Vane 1 TE Reheat ............................. 15

Figure 8 - Local Minimum in Residence Time - Vane 1 TE Reheat for 150 C Boost 16

Figure 9 - Projected NOx and CO Emissions ............................................. 16 


\section{INTRODUCTION AND BACKGROUND}

Cooperative Agreement No. DE-FC26-00NT40913, "Gas Turbine Reheat Using In-situ Combustion," between Siemens Westinghouse Power Corporation and the United States Department of Energy began on October, 1, 2000, and IS scheduled to end on May 31, 2004.

The overall objective of this project is to develop a novel gas reheat concept for gas turbine engines, in which fuel is injected directly into the turbine through one or more stages of vanes and/or blades. The key research goals involved in concept selection are to understand the combustion kinetics (burnout, emissions), blade performance and effects on turbine power output and efficiency. The concept is being evaluated for maximum energy efficiency (full reheat) and as a means to achieve power boost (minimum reheat)

Background. Increasing gas turbine firing temperature has historically increased gas turbine efficiency and power output. This approach is limited by the generation of thermal NOx and by the need for advanced materials at higher temperatures.

A well-known alternative approach is to add reheat combustion between turbine stages to achieve higher mean temperatures at which heat is extracted, without increasing maximum temperature. More fuel is burned, to give higher power output. If this is accompanied by increased pressure ratio, or used in combined cycle with higher steam cycle inlet temperature, then cycle efficiency is also increased.

Prior suggested reheat schemes have used discrete reheat combustors, either within a larger shell or externally, between two separate turbines. In the concept of this work [1], reheat fuel is injected directly into the turbine flow via injection holes in the turbine vanes or blades. The advantages are: 1) simplicity in turbine design with no increase in casing size and no external reheat combustor and transition. 2) Lower reheat peak combustion temperature; 3) near zero reheat NOx formation, with normalized NOx (to 15\% oxygen) actually reduced; 4 ) reduced parasitic pressure loss; 5) substitution of fuel for some airfoil coolant flow.

Relevancy. The in-situ reheat concept represents a new approach that can allow gas turbine engines to move toward DOE goals of higher efficiency, higher power output, low emissions engines. This work will develop the scientific basis for the concept of in-situ reheat. Also, this work provides a platform for continuing development for engine applications in IGCC plants burning syngas or fuels containing high hydrogen content (zero emissions power plants). In particular the work will identify the combustion kinetic basis for injection, will identify practical designs (simple or flame-held) for achieving injection, and will quantify effects on airfoil aerodynamics and turbine performance.

The project is divided into four technical tasks:

Task 1, Blade Path Aerodynamics (performed by Texas A\&M University). A CFD model, CoRSI (Combustion and Rotor-Stator Interaction) was to incorporate simplified combustion kinetics with blade path flow. The model was used to investigate the effect of injection parameters (stage, fuel flow, fuel temperature, injection angle) on turbine performance (burnout location, forces on blades, power output, efficiency).

Task 2, Combustion and Emissions. Detailed (Chemkin and GRI data base) calculations are being performed to characterize reheat fuel burnout and emissions kinetics. Calculations are aimed at flameless (simple injection) and flame-held injection designs. 
Task 3, Sub-Scale Testing. Direct injection is being studied experimentally in high-pressure, high-temperature test rigs. Blade path temperatures and velocities are used, with reduced pressure. The progress of direct injection combustion is being measured as a function of residence time. Results are used to calibrate Task 2 modeling and to check Task 1 model results.

Task 4, Conceptual Design and Development Plan. A preferred design approach will be identified and prepared for pre-commercial development based on the results of prior tasks.

The present document is the required Topical Report on Task 2. 


\section{PRELIMINARY NON-FLAMEHOLDING ANALYSIS}

The CHEMKIN detailed kinetic model, one-dimensional plug-flow, was used with the GRI detailed kinetics database to characterize burnout as a function of conditions in the blade path. In these calculations, complete mixing of the fuel and main gas was assumed to occur at the injection point. Furthermore, these injections were assumed to occur without the benefit of a flameholder, i.e. a geometry that would provide a sheltered recirculation zone.

Figures $1 \mathrm{a}$ and $1 \mathrm{~b}$ show burnout with injection at the trailing edge of a typical first stage vane, and with injection at the trailing edge of a second stage vane after first stage injection. For first stage injection there is an ignition lag that causes fuel burnout around the following blade. For second stage injection following first stage injection, burnout begins in the vicinity of the blade, but is slow and is not complete until the flow approaches the leading edge of the next vane. Non-flameholder ignition for second stage injection without first stage injection is not predicted.

No NOx formation occurs with this injection, for these assumptions, so that total molar NOx emissions are the same as for no reheat. Since NOx emissions are normalized to $15 \%$ oxygen (to make NOx emissions per mole of fuel the emissions criteria), the normalized emissions go down with reheat. For one and two stages of reheat the normalized NOx emissions are $15 \%$ and $26 \%$ lower than for no reheat.

Figure 2 summarizes temperature and NOx effects.

Added CO for one stage of reheat, by the end of fuel burnout are about +10 ppmv. This will likely burnout in the balance of the turbine. Added $\mathrm{CO}$ for a second stage of reheat by the end of fuel burnout is about +100 ppmv, and burnout downstream is problematic.

\section{Streamline Flow Reactor Model \\ Vane 1 injection}

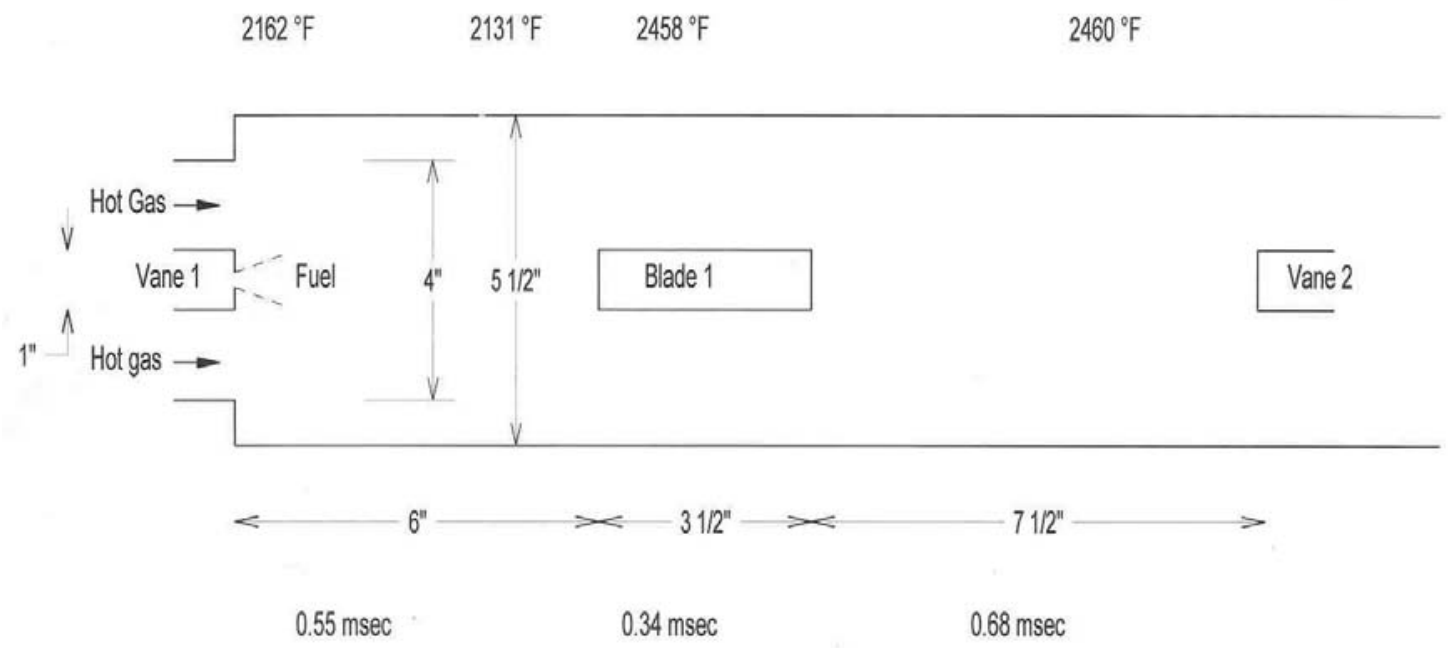

Figure 1a - Vane 1 Injection Kinetics. 


\section{Streamline Flow Reactor Model}

Vane 2 injection after Vane 1 injection

\section{$2160^{\circ} \mathrm{F}$}

$2160^{\circ} \mathrm{F} \quad 2384^{\circ} \mathrm{F}$

$2457^{\circ} \mathrm{F}$
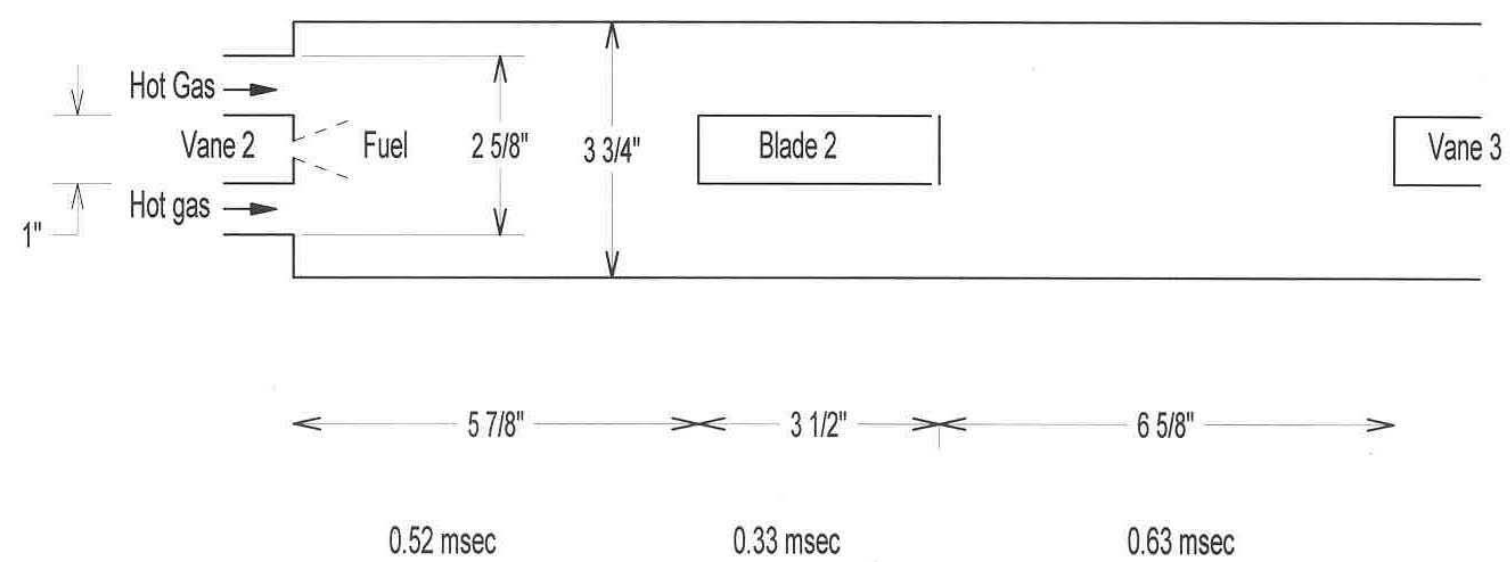

Figure $1 \mathrm{~b}$ - Vane 2 Injection Kinetics.

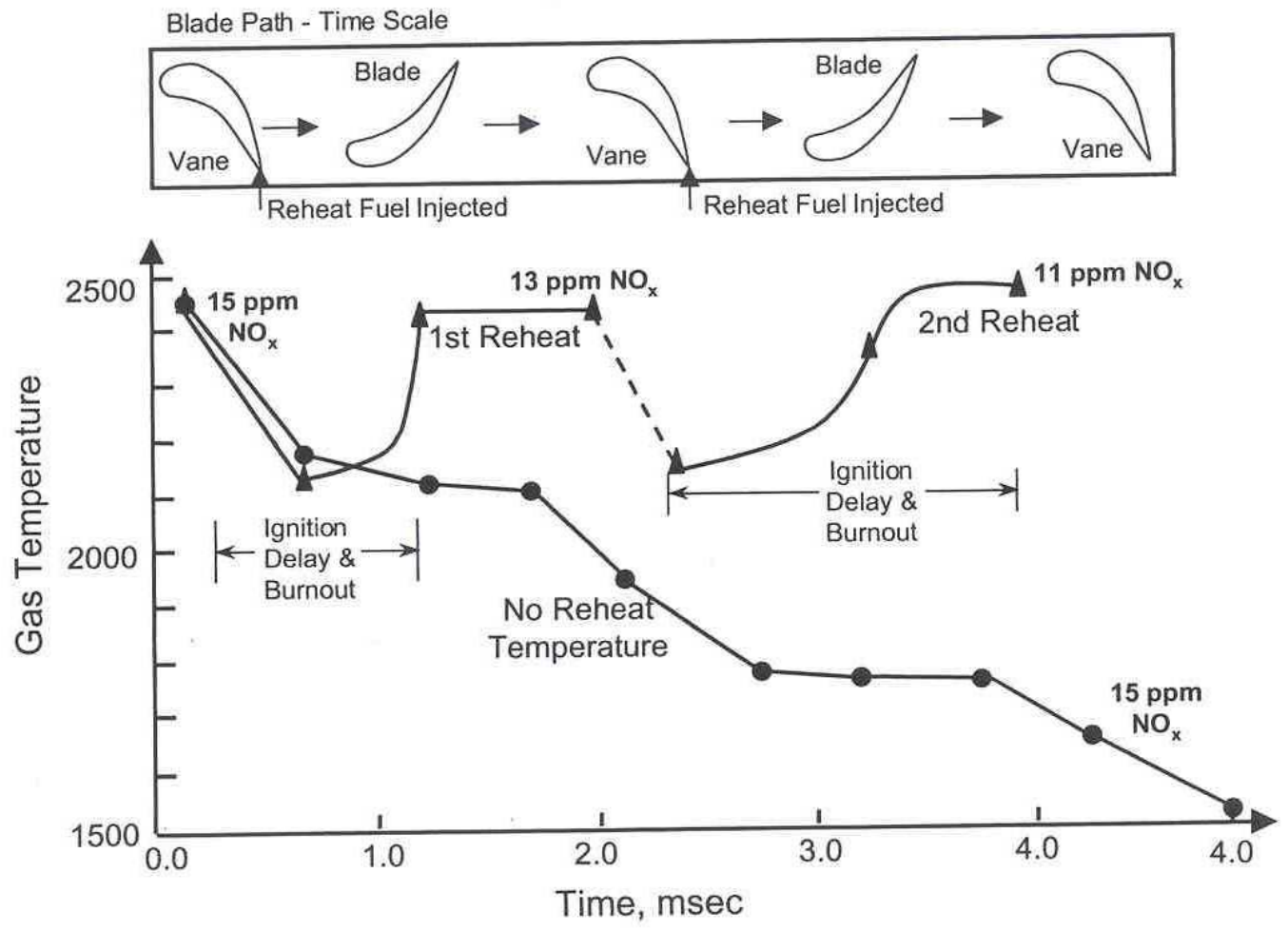

Figure 2 - Blade Path Temperature and NOx with 2-stage Reheat. 


\section{NON-FLAMEHOLDING DESIGN CONCEPT}

\subsection{Modeling Approach}

For non-flameholding design concepts, fuel is injected directly through small holes in the trailing edges of blades or vanes. The chemical kinetics versus length through the turbine for this case were estimated using a proprietary Siemens Westinghouse computer model, DFLAME, for calculating flame sizes, residence times, and chemical kinetics of diffusion flames. The reheat calling program provides blade path conditions varying with axial position to DFLAME, and calculates post-flame continuation of combustion, to estimate burnout, emissions, and possible streaking.

The burnout kinetics for the post-flame zone were calibrated using the test data from the present project. Then, the overall model was used to project performance and emissions for a variety of parametric cases.

\subsubsection{Calling Module}

The main module for reheat kinetic calculations follows the progress of the injected fuel and jet-entrained bulk gas, until the identity of these jets vanishes; and then follows the resulting total bulk gas mixture to the end of the turbine, calculating kinetics as it goes. In this way final conversion and emissions are determined, and streaking is identified by the way the jet flames and plumes.

The program proceeds by the following steps:

1) Input parameters are read: reheat fuel composition, flow rate, temperature; number and size of holes per vane; main gas flow and composition into vane 1.

2) Also read are path conditions at each station: axial position, gas angle, flow area normal to axis, static pressure, static temperature, cumulative cooling air flow, and number of airfoils. Stations are the leading and trailing edge axial locations for each airfoil.

3) The initial velocity and density of the injected fuel are determined, as limited for sonic flow.

4) The diffusion flame model (DFLAME, see Section 3.1.2) is repeatedly used to determine diffusion flame length (stoichiometric entrained main gas/fuel ratio) and final width, plume length and width, and resulting composition and temperature for each. The diffusion flame is defined as the stoichiometric mixture of reheat fuel and entrained bulk gas. It may or may not be lit, as determined by DFLAME. The "plume" is defined as the continuation of the diffusion flame by addition of entrained main gas in increments until the jets merge. The calling program provides an effectiveness factor, i.e. a residence time multiplier used to account for imperfect mixing, to DFLAME for plume increments. At each increment, conditions, both jet and surrounding, are recorded. These include: axial location, jet mass flow, cumulative jet gas residence time, jet temperature, bulk gas temperature, carbon conversion, and $\mathrm{CO}$ and NOx raw ppmv. The jet gas composition is recorded at the end of the diffusion flame and at the end of the plume.

5) The remaining bulk gas at the end of the plume is mixed into the plume product gas to form the initial total gas mixture.

6) The total gas mixture is followed through the rest of the turbine, station by station. The gas mixture temperature (initially higher than for non-reheat operation) and pressure are assumed to fall in increments as per the non-reheat case. For each such step (plume to 
next station and then station to station) additional cooling air is mixed in, the residence time is determined, and chemical kinetics are calculated using the CHEMKIN plug flow module with GRI 3.0 kinetics, resulting in composition and additional temperature change. An effectiveness factor is determined. At each increment conditions are recorded, including: station number, axial location, mass flow, cumulative gas residence time after plume, gas temperature, carbon conversion, and $\mathrm{CO}$ and NOx raw ppmv. The final station gas composition is then recorded, as well as the normalized (15\% O2, dry) $\mathrm{CO}$ and NOx.

\subsubsection{Diffusion Flame Model}

\section{Overall Structure.}

The model (DLAME) calls several modules of the CHEMKIN Collection, which uses the GRI 3.0 kinetic database. It proceeds according to the following steps. Italicized statements indicate functions of the calling program external to DFLAME.

1) For each jet length increment, steps 2 through 10 are executed. Recall that the first increment corresponds to the diffusion flame, and subsequent increments to portions of the plume.

2) The total jet length through this increment is guessed. The end position blade path conditions are provided by the calling module.

3) The composition of the total bulk gas (initial bulk gas and incremental cooling air) is calculated.

4) The jet equivalence ratio for the increment is known from the definition of the increment. The bulk gas entrainment to achieve this equivalence ratio is determined.

5) The mass flow, composition, and temperature of the mixture are calculated. For the first increment (diffusion flame) this is the mixture of fuel and entrained gas. For subsequent increments this is the mixture of the reacted product from the previous increment and the additional entrained gas.

6) The equilibrium composition and temperature are calculated.

7) The diffusion flame (or flame plus plume) length and width are calculated based on the methods in the following subsections.

8) This length is compared to that guessed in step 2. If they are the same, the calling program uses the sequence of gas angles to calculate the axial end location for the increment, and DFLAME proceeds to step 9. If not, a new length is guessed and DFLAME returns to step 2 .

9) The volume of the increment and the residence time of gases in it are calculated using this volume, the flow rate from step 5, and the temperature and molecular weight from step 6.

10) The kinetics of the jet flame is calculated using the CHEMKIN code, the GRI 3.0 kinetic database, the initial composition and temperature from step 5 , and the residence time from step 8. For the first (diffusion flame) increment only this residence time is divided into a well-stirred portion followed by a plug-flow portion. For plume increments the residence time is all plug-flow. This residence time is multiplied by an "effectiveness factor" to account for imperfect mixing. The diffusion flame effectiveness factor is internal to 
DLAME, based on prior data. For the plume segments this effectiveness factor is provided by the calling program.

\section{Jet Diameter}

A jet of the nozzle fluid reactant (usually fuel) issues from a nozzle into a stream of flowing mainstream reactant (usually oxidant). The model for circular turbulent jet flames into a stagnant main stream is that of Hawthorne, Weddell, and Hottel [2]. Expansion of the model to a co-flowing main stream has been added.

A mass balance on nozzle fluid at constant pressure on nozzle fluid gives

$$
\frac{D^{2} V C \alpha}{T}=\frac{D_{n}^{2} V n}{T_{n}}
$$

A momentum balance from the nozzle plane gives

$$
D^{2} V^{2} \rho=D_{n}^{2} V_{n}^{2} \rho_{n}+\left(D^{2}-D_{n}^{2}\right) V_{a}^{2} \rho_{a}
$$

and the density ratios are

$$
\frac{\rho}{\rho_{n}}=\left[C+\frac{M_{a}}{M_{n}}(1-C)\right] \frac{\alpha T_{n}}{T}
$$

and

$$
\frac{\rho_{a}}{\rho_{n}}=\frac{M_{a}}{M_{n}} \frac{T_{n}}{T_{a}}
$$

At the nozzle plane,

$\mathrm{D}_{\mathrm{n}} \quad=$ nozzle inside diameter

$\mathrm{V}_{\mathrm{n}} \quad=$ velocity of nozzle fluid exiting nozzle

$\mathrm{T}_{\mathrm{n}} \quad$ = temperature of nozzle fluid

$M_{n} \quad$ = molecular weight of nozzle fluid

$\rho_{\mathrm{n}} \quad=$ density of nozzle fluid

$\mathrm{V}_{\mathrm{a}} \quad=$ velocity of entrained main-stream fluid

$\mathrm{T}_{\mathrm{a}} \quad$ = temperature of entrained main-stream fluid

$\mathrm{M}_{\mathrm{a}} \quad=$ molecular weight of entrained main-stream fluid

$\rho_{\mathrm{a}} \quad=$ density of entrained main-stream fluid

and, at any height of interest

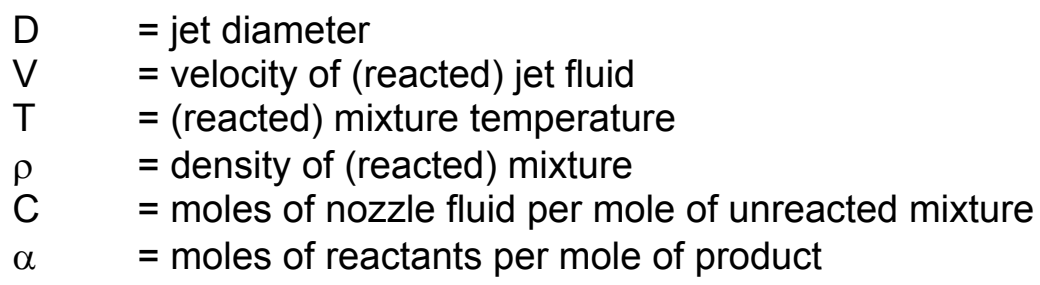


Combining equations 1 through 4 gives

$$
D=D_{n} \sqrt{x}
$$

the equation for the jet diameter at any stoichiometry (defined by $C$ and $\alpha$ ), where $x$ is a root of

$$
a x^{2}+b x+c=0
$$

in which

$$
\begin{gathered}
a=\left(\frac{V_{a}}{V_{n}}\right)^{2} \frac{M_{a} T_{n}}{M_{n} T_{a}} \\
b=1-a \\
c=-\frac{1}{C^{2}}\left[C+\frac{M_{a}}{M_{n}}(1-C)\right] \frac{T}{\alpha T_{n}}
\end{gathered}
$$

Note that Equations 5 through 9 reduce to the solution by Hawthorne et al. [ref. 2, eq. 32] for a stagnant main stream if $\mathrm{V}_{\mathrm{a}}=0$.

Hawthorne et al. [2] originally applied this model to what we call in this report the diffusion flame, i.e. the region containing stoichiometric fuel and air. There is no reason it cannot be applied to other stoichiometries, representing the plume increments in this case, as we have done simply by using the appropriate values of $C$ and $\alpha$.

For reheat applications, the calling program scales the final diameter by the ratio of the projected area along the flow path at the end of the jet to the projected area along the flow path at the beginning of the jet.

\section{Jet Length}

Wohl, Gazley, and Kapp [3] developed a theoretical expression for lengths of laminar diffusion flames. In DFLAME, this is used for turbulent diffusion flames, with substitution of the eddy diffusivity for molecular diffusivity.

The flame length is then

$$
H=\frac{Q}{-4 \pi K \ln (1-C)}
$$

where

$$
\begin{aligned}
& H=\text { flame length } \\
& Q=\text { volumetric flow rate of nozzle fluid (fuel) } \\
& C=\text { moles of nozzle fluid per mole of the unreacted mixture } \\
& \mathrm{K}=\text { eddy diffusivity }
\end{aligned}
$$

The eddy diffusivity definition used is based on Turns [4]: 


$$
K=0.0285 \cdot V_{e} R
$$

Turns's development is for a jet into a stagnant medium, so his $\mathrm{V}_{\mathrm{e}}$ is the nozzle velocity. In the present case, the jet is into a co-flowing stream, and we have found that the appropriate representative velocity for use in eq. (11) is

$$
V_{e}=\sqrt{V_{n} \cdot \mid\left(V_{a}-V_{n} \mid\right.}
$$

This accounts for both the kinetic energy of the nozzle fluid and the shear between nozzle fluid and surrounding fluid.

Again $\mathrm{C}$ is adjusted for the stoichiometry of the increment.

\section{Jet Volume and Reactant Residence Time}

The jet volume is determined by the conic frustum with one base area $\left(A_{1}\right)$ equal to the nozzle diameter and the other $\left(A_{2}\right)$ by the final jet width:

$$
\text { Volume }=H / 3 \cdot\left(A_{1}+A_{2}+\sqrt{A_{1} A_{2}}\right)
$$

The jet is assumed to expand and contract along its path in proportion to the projected crosssectional area along the path, which changes because of expansion of turbine cross-section and variation of gas angle. The final volume is adjusted by the calling program to account for this.

\subsubsection{Empirical Factors}

The experimental data from the present project (Task 3, see Section 3.2 below) was used to calibrate the reheat model. The effectiveness factor used as a multiplier for residence times in plume and post-plume kinetic calculations was used as the empirical factor. It may be interpreted as a fall-off in rate due to mixing limitations, with products insulating the surviving fuel pockets from the surrounding oxygen supply.

$$
\eta=(1-X)^{n}
$$

where

$$
\begin{aligned}
& \eta=\text { effectiveness factor } \\
& X=\text { fractional carbon conversion } \\
& n=\text { empirical constant, found to be } 1.6
\end{aligned}
$$

with $\eta$ limited to a minimum value of 0.06 .

\subsection{Fit to Experimental Data}

In Task 3 of this program subscale testing of reheat burnout kinetics was conducted. The test rig is shown schematically in Figure 3 . In it, an air flow of up to $0.2 \mathrm{~kg} / \mathrm{s}(0.44 \mathrm{lb} / \mathrm{sec})$ at conditions of up to $755 \mathrm{~K}\left(900^{\circ} \mathrm{F}\right)$ and $13.8 \mathrm{bar}(200 \mathrm{psia})$ fired a full pressure (14 bar) natural 
gas-fired dump combustor to generate a hot flue gas. Fuel/air ratio and air inlet temperature are varied to give product temperatures and compositions corresponding to typical turbine locations as a function of blade path position. In each case the product mixture is passed through a pressure-reducing orifice (to about 5.5 bar ( 80 psia)) to raise the Mach number in the test channel to a level representative of an industrial gas turbine. This is necessary because the available air flow precludes maintaining both pressure and velocity in a channel of acceptable size.

The gas mixture enters a rectangular $1.78 \mathrm{~cm} \times 2.54 \mathrm{~cm}(0.7 \mathrm{in} \times 1.0 \mathrm{in})$ channel and passes a probe that crosses the centerline of the channel. The probe is used to inject fuel via a hole in its trailing edge. The geometry of the probe is shown in Figure 4. Fuel is injected through a $0.66 \mathrm{~mm}(0.026 \mathrm{in})$ diameter hole. Following the probe, the gas and fuel jet enter a $1.78 \times 1.78$ $\mathrm{cm}(0.7$ in $\times 0.7$ in) test channel. Temperature and gas composition are measured with centerline sampling probes at several locations in the test section.

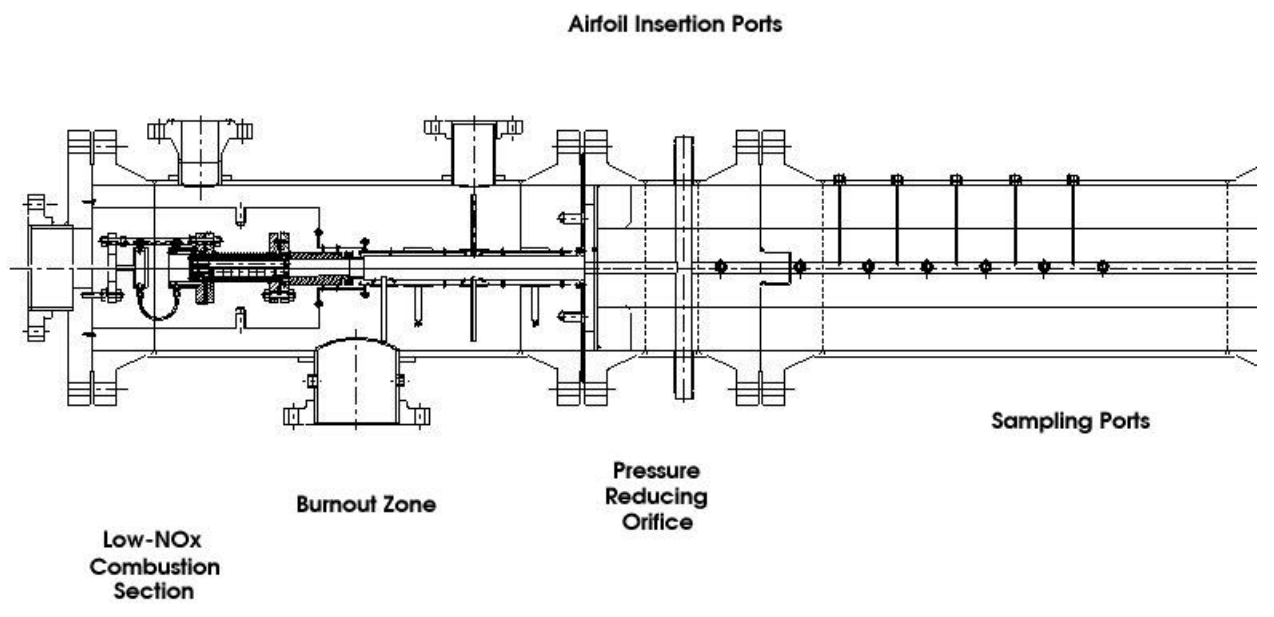

Figure 3 - Experimental Apparatus. 

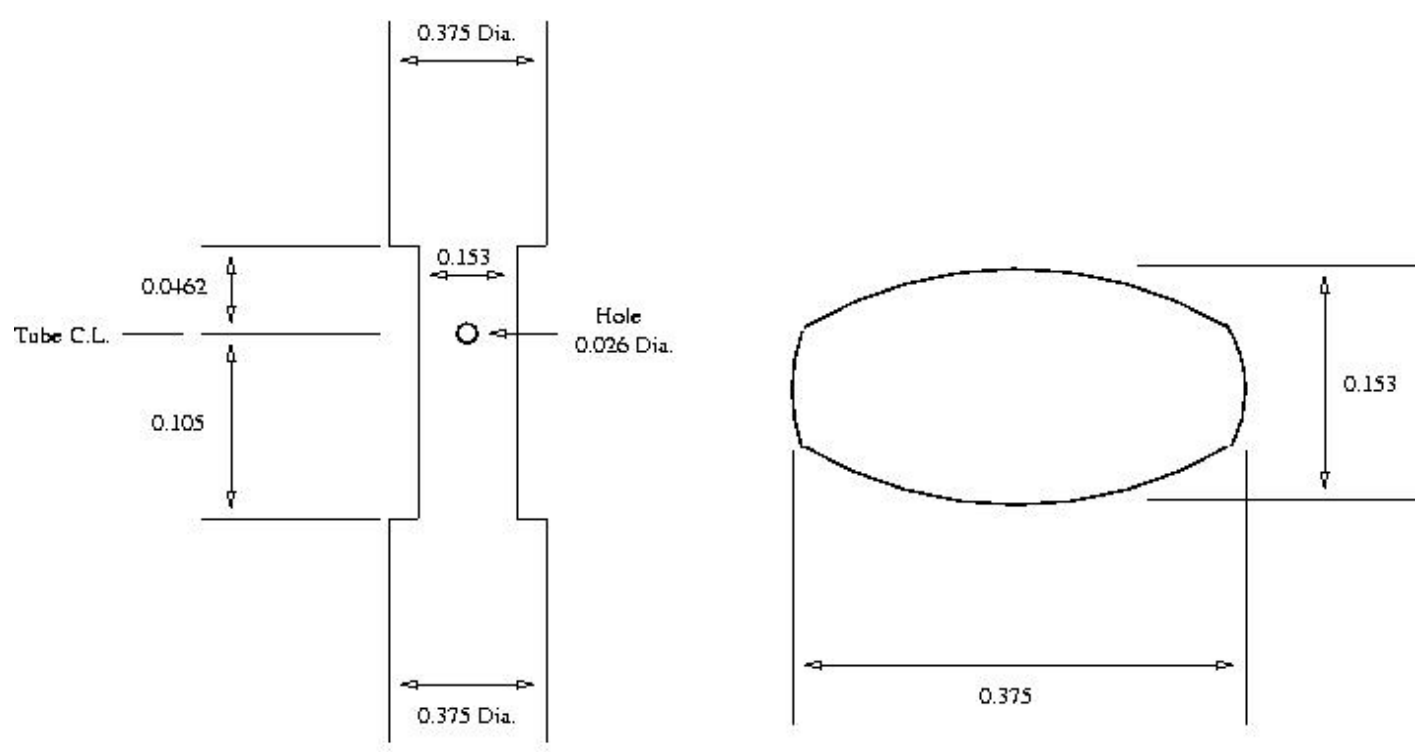

NOTE: Al] Lengths Shown in Inches

Deawing Not To Scale

Figure 4 - Combustion Probe.

With fuel injection at conditions corresponding to V1 trailing edge and B1 mid way, burnout was complete prior to the first sampling probe, so these could not be used to calibrate the model. With injection at conditions corresponding to B1 trailing edge and V2 trailing edge, combustion was incomplete, so these points could be so used. Table 1 presents some conditions for several such runs. The natural gas was at $289 \mathrm{~K}$, with a mole percent composition of approximately $96.1 \mathrm{CH} 4,2.0 \mathrm{C} 2 \mathrm{H} 6,0.9 \mathrm{C} 3 \mathrm{H} 8,0.5 \mathrm{CO} 2$, and $0.5 \mathrm{~N} 2$. 
Table 1 - Test Conditions

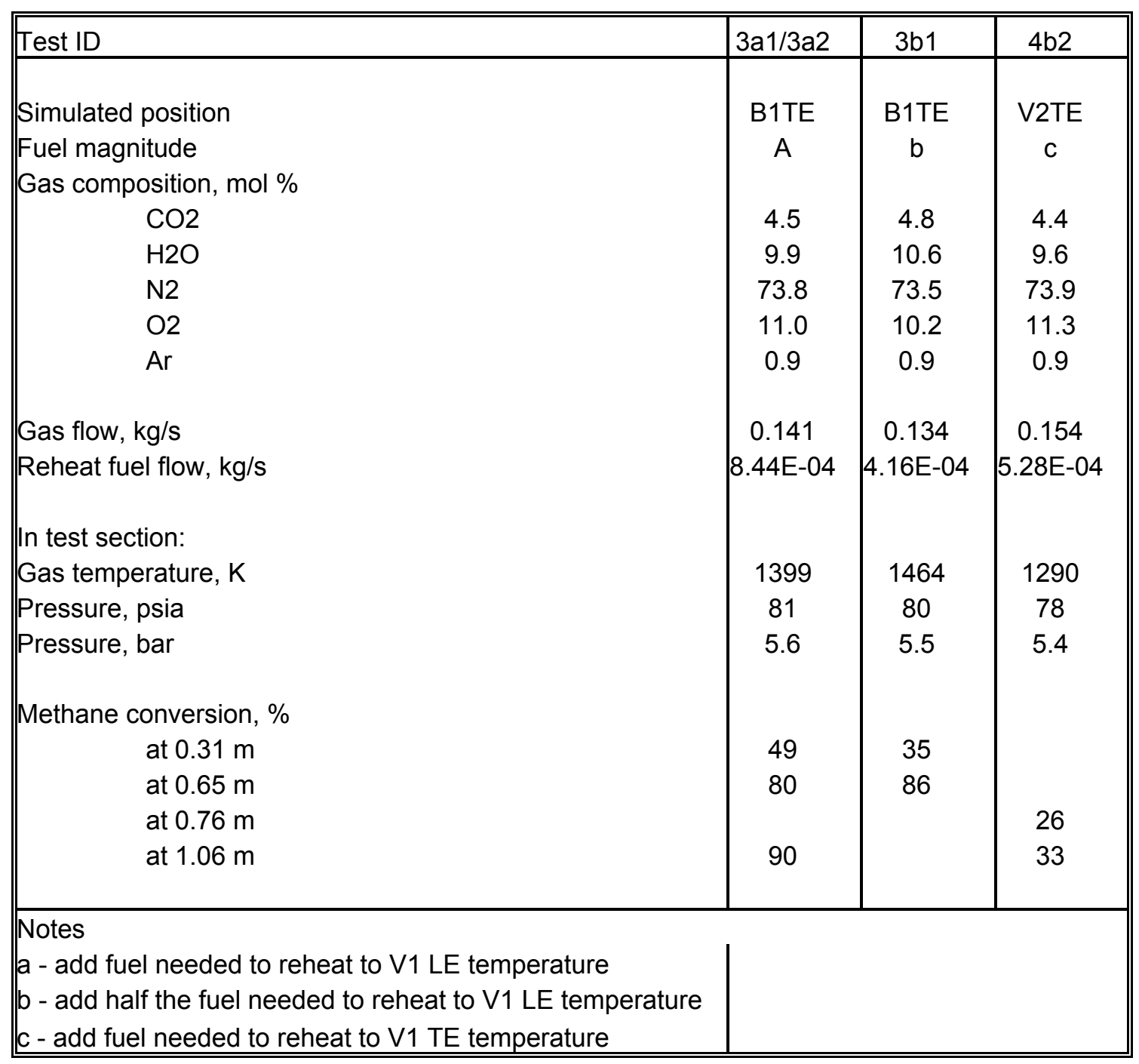


Figure 5 presents the fit of the test data (squares) with the model projections, using the empirical factors from Section 3.1.3 above.
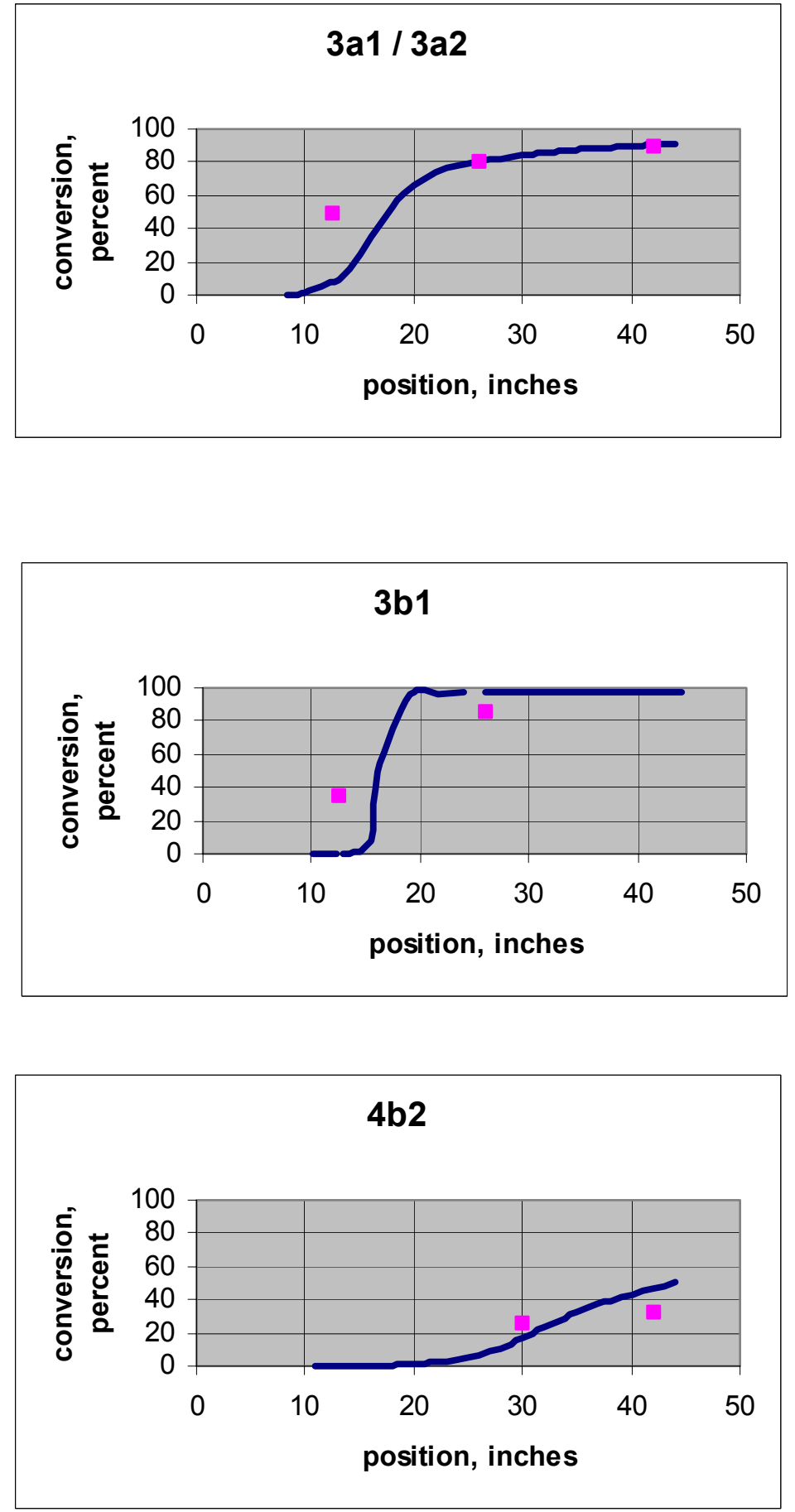

Figure 5 - Carbon Conversion - Model vs Data

\subsection{Parametric Study Results}

The model presented and calibrated in Sections 3.1 and 3.2 was used to explore reheat performance in terms of burnout, streaking, and emissions as functions of location (station) of fuel injection, amount of fuel, hole size, and number of holes. Recall that the diffusion flame is 
defined as that structure contain fuel and a stoichiometric amount of entrained main gas; and that it may or may not be lit, as determined by kinetics.

In all of the following cases it is assumed that the main gas entering the turbine has no CO, and has sufficient NOx to give 8 ppmv normalized NOx at the exit of the turbine after mixing with all cooling air and without reheat.

\subsubsection{Four-Stage Turbine, Vane 1 Injection}

Table 2 and Figures 6 through 9 summarize calculations for injecting sufficient fuel at the vane 1 trailing edge to achieve a $150 \mathrm{C}$ temperature boost, i.e. to return the gas stream temperature to about the vane 1 inlet temperature.

The first five of the six blocks of data in Table 2 show how reheat proceeds as a function of hole size and number $(\mathrm{N})$ at constant total fuel flow. In the first block, the hole size varies, and the number of holes also varies in order to keep the fuel flux (fuel per second per unit total hole area). Thus each block is at a constant fuel velocity. Figures 6 and 7 show how emissions are projected to vary.

At constant velocity (fuel flux), each dimension of the diffusion flame scales (approximately) with hole size, so the diffusion flame volume scales (approximately) with the cube of hole size. Also, the volumetric flow scales with the square of hole diameter. Therefore, the residence time (volume $\div$ volumetric flow) scales linearly with hole size. This is evident in each of the first five blocks in Table 2.

In the first block (number of holes varies to keep fuel flux at $0.08 \mathrm{~kg} / \mathrm{s}-\mathrm{cm} 2$ ), the injected fuel burns as a diffusion flame when using a $3.2 \mathrm{~mm}$ hole size, since there is sufficient high temperature residence time to ignite, resulting in significant NOx emissions. When the hole size is reduced, there is insufficient residence time to hold a lit diffusion flame, and burnout occurs slightly downstream. By this time the jet has been diluted with more entrained gas, resulting in cooler burning, with lower NOx, which continues to decrease with decreasing hole size because of the lower residence time in the plume which follows the same rules as residence time in the diffusion flame. Burnout location (defined here as where $50 \%$ conversion has occurred) also moves upstream in the turbine, so that hotter gases are entrained and burnout zone temperatures become higher. Eventually the effect of hotter burning overcomes the effect of reduced residence time, and NOx begins to increase again. The second $(0.095 \mathrm{~kg} / \mathrm{s}-\mathrm{cm} 2)$ and third $(0.12 \mathrm{~kg} / \mathrm{s}-\mathrm{cm} 2)$ blocks, with fewer holes, follow the same pattern.

For $\mathrm{CO}$, there is also a trade-off, for opposite reasons. Smaller holes mean less residence time for $\mathrm{CO}$ burnout, but higher burnout temperatures for more rapid burnout. Again there is an optimum, as seen in the second and third blocks.

The change in gas angles through the turbine can influence emissions. This is seen in the fourth block in Table 2. A diffusion flame is normally not stable for hole sizes below $1 \mathrm{~mm}$, following the same trend as previous blocks. However, there is an apparently anomalous lack of diffusion flame at the $2.2 \mathrm{~mm}$ hole size. The reason is a local minimum in residence time. This is explained with reference to Figure 8 . The volume of the 8-hole flame is almost as low as the volume of the 12 hole flame. This is because the end of the flame lies along the trailing edge the first rotor where the gas angle with respect to the axis is high and the projected cross-sectional area along this path is low; the end of this flame contributes little volume and hence residence time.

The fifth block in Table 2 and Figure 9 show the effect of number of holes at constant hole size. Note that as the number of holes decreases, the velocity issuing from the holes 
increases. As velocity increases there is less shear with the surrounding high velocity gas stream, so the flame spreads more slowly, becoming longer and wider. Jet volume per hole increases more rapidly that flow per hole, the residence time increases. There is again a tradeoff of time and temperature causing minima in emissions for both $\mathrm{CO}$ and NOx in the cases where the diffusion flame is not lit.

Table 3 shows that increasing reheat fuel will cause an increase in emissions.

In summary, for Vane 1 reheat without flameholding, there is projected to be an optimum design with a hole size of about $1.8 \mathrm{~mm}$ and a fuel flux of $0.12 \mathrm{~kg} / \mathrm{s}-\mathrm{cm} 2$ (i.e. 24 holes per vane). NOx and $\mathrm{CO}$ are higher by about 6 ppmv and 9 ppmv (corrected), respectively, than without reheat (bulk 8 ppm NO, 0 ppm CO assumed). Also, contrary to initial hypothesis, there is not always an advantage to go to a smaller hole size. There is actually an optimum hole size. This means that design will be more sensitive and uncertain, given uncertainties in the modeling. Further, emissions will increase for increasing reheat rates.

Table 2 - Vane 1 Trailing Edge Reheat, Fuel for $150 \mathrm{C}$ Boost

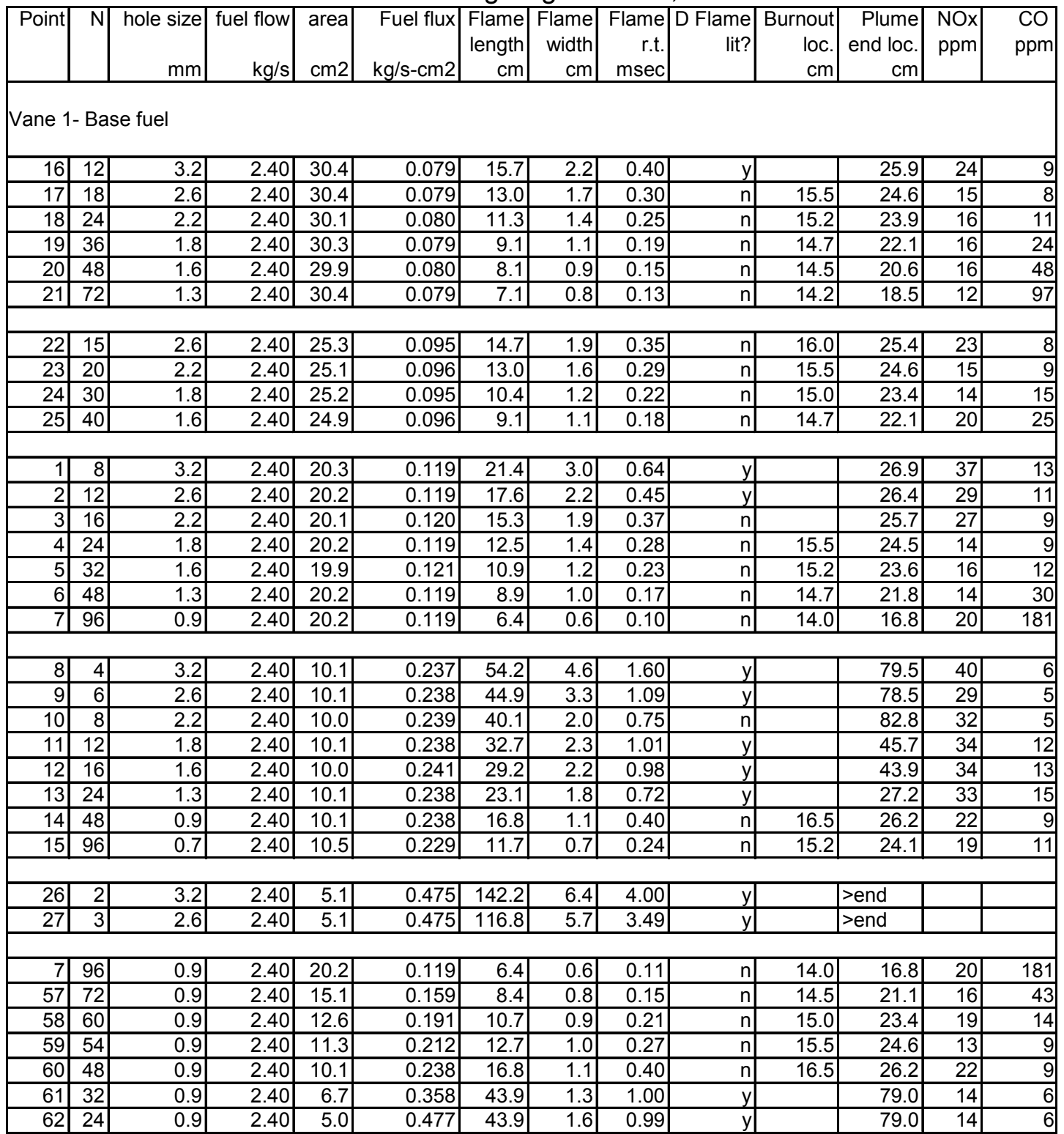




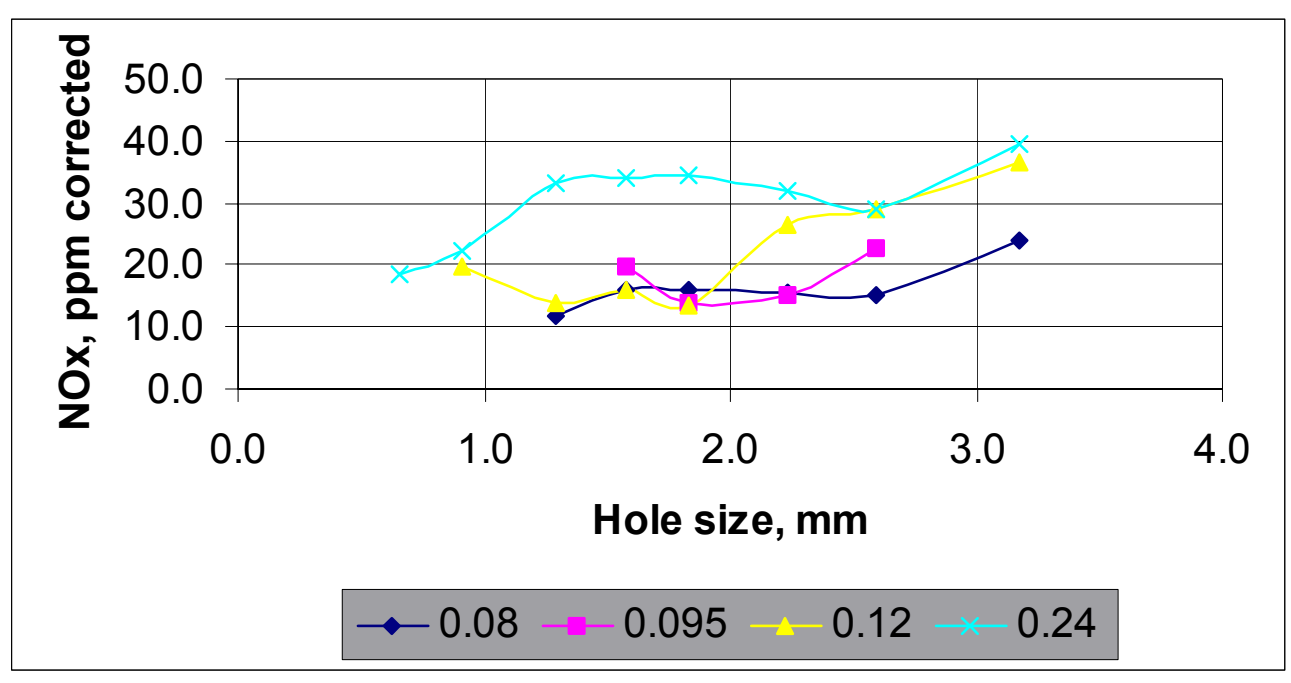

Figure 6 - Projected NOx Emissions - Vane 1 TE reheat for $150 \mathrm{C}$ boost. (Legend is fuel flux, $\mathrm{kg} / \mathrm{m} 2 \mathrm{sec}$, and represents varying the number of holes per vane while keeping total fuel constant)

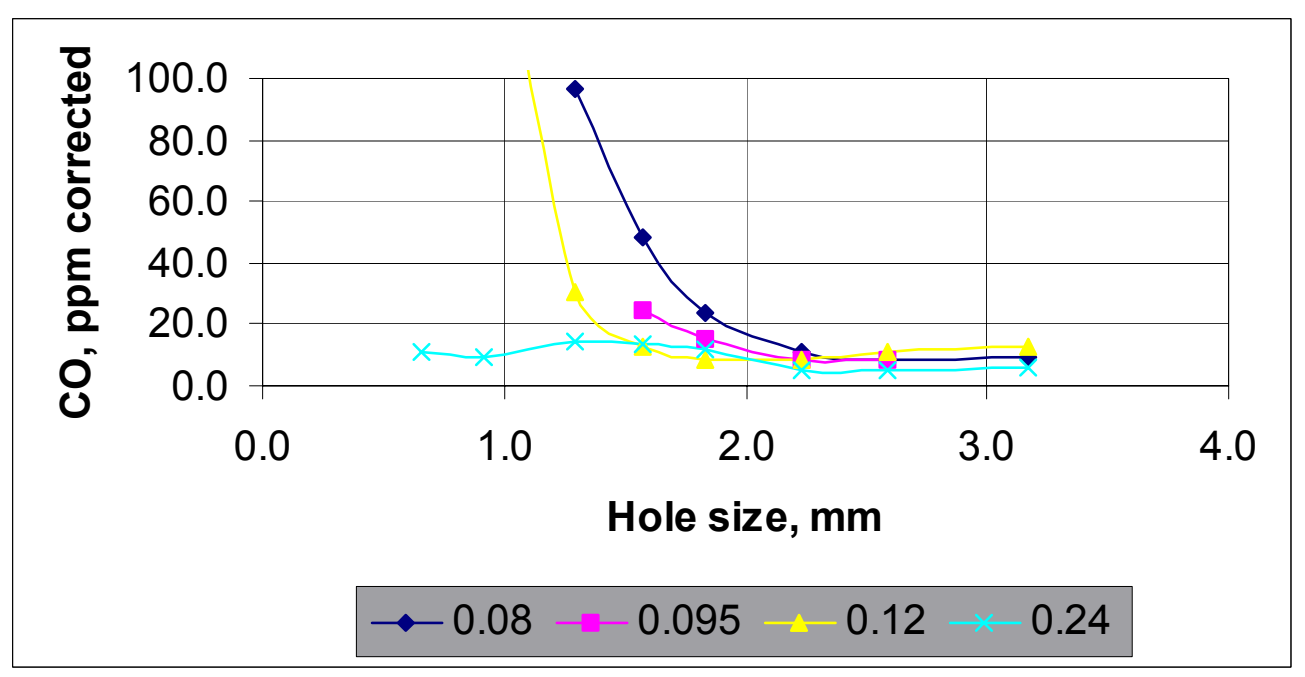

Figure 7 - Projected CO Emissions - Vane $1 \mathrm{TE}$ reheat for $150 \mathrm{C}$ boost. (Legend is fuel flux, $\mathrm{kg} / \mathrm{m} 2 \mathrm{sec}$, and represents varying the number of holes per vane while keeping total fuel constant) 


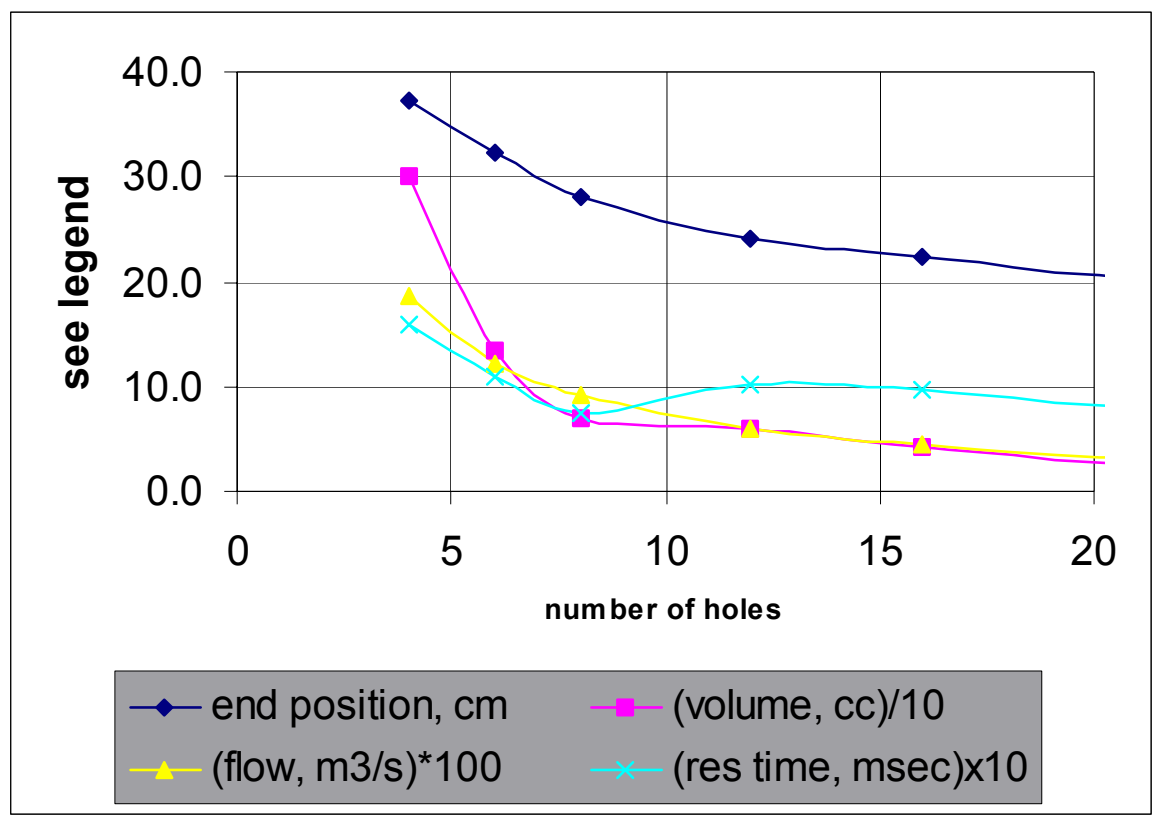

Figure 8 - Local Minimum in Residence Time - Vane 1 TE Reheat for 150 C Boost.

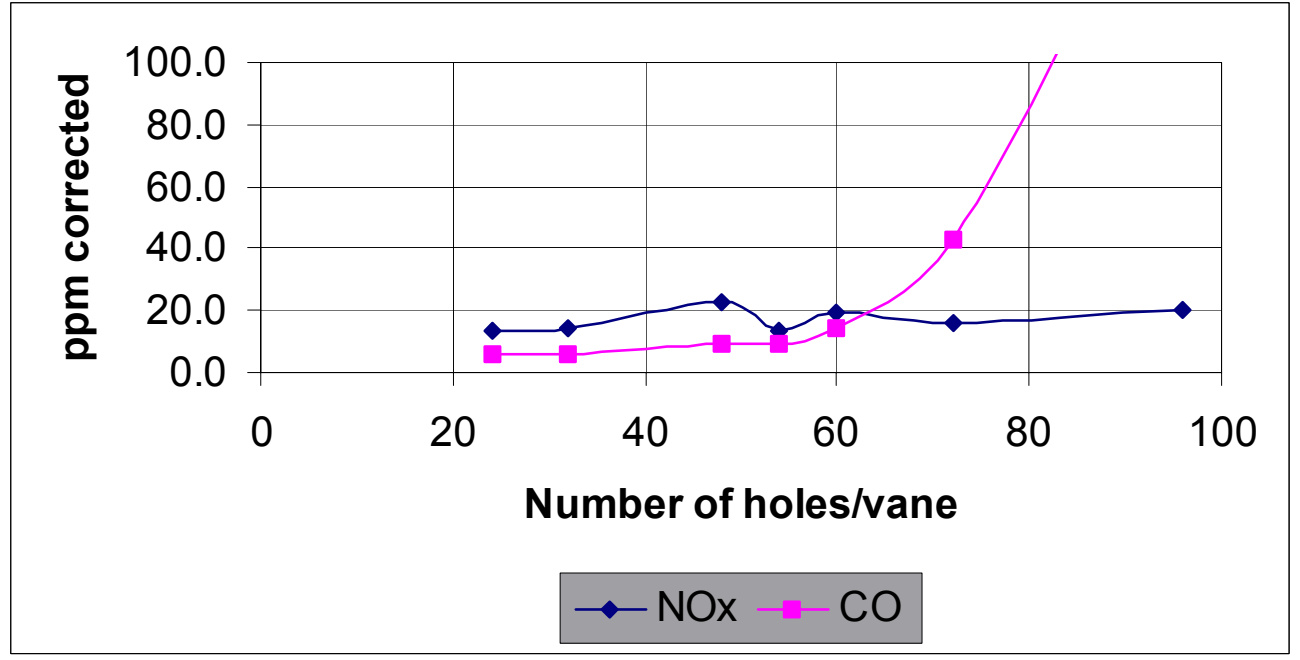

Figure 9 - Projected NOx and CO Emissions as a Function of Number of Holes at Constant $0.9 \mathrm{~mm}$ Hole Size - Vane 1 TE Reheat for 150C Boost. 
Table 3 - Vane 1 Trailing Edge Reheat, Fuel for 300 C Boost

\begin{tabular}{|c|c|c|c|c|c|c|c|c|c|c|c|c|c|}
\hline Point & $\mathrm{N}$ & $\begin{array}{r}\text { hole size } \\
\mathrm{mm} \\
\end{array}$ & $\begin{array}{r}\text { fuel flow } \\
\mathrm{kg} / \mathrm{s} \\
\end{array}$ & $\begin{array}{l}\text { area } \\
\mathrm{cm} 2 \\
\end{array}$ & $\begin{array}{r}\text { Fuel flux } \\
\mathrm{kg} / \mathrm{s}-\mathrm{mm} 2\end{array}$ & \begin{tabular}{|r|} 
Flame \\
length \\
$\mathrm{cm}$ \\
\end{tabular} & \begin{tabular}{|r|} 
Flame \\
width \\
$\mathrm{cm}$ \\
\end{tabular} & $\begin{array}{r}\text { Flame } \\
\text { r.t. } \\
\text { msec } \\
\end{array}$ & \begin{tabular}{|r|} 
D Flame \\
lit?
\end{tabular} & \begin{tabular}{|r|} 
Burnout \\
loc. \\
$\mathrm{cm}$ \\
\end{tabular} & $\begin{array}{r}\text { Plume } \\
\text { end loc. } \\
\mathrm{cm}\end{array}$ & $\begin{array}{l}\text { NOx } \\
\text { ppm }\end{array}$ & $\begin{array}{l}\mathrm{CO} \\
\mathrm{ppm}\end{array}$ \\
\hline \multicolumn{14}{|c|}{ Vane 1 - Double fuel } \\
\hline 34 & 24 & 2.6 & 4.81 & 40.5 & 0.119 & 17.5 & 2.2 & 0.45 & $y$ & & 23.9 & 39 & 20 \\
\hline 35 & 48 & 1.8 & 4.81 & 40.3 & 0.119 & 12.4 & 1.4 & 0.28 & $\mathrm{n}$ & 15.5 & 20.8 & 17 & 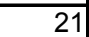 \\
\hline 36 & 64 & 1.6 & 4.81 & 39.9 & 0.121 & 10.9 & 1.2 & 0.23 & $\mathrm{n}$ & 15.2 & 18.8 & 17 & \\
\hline & & & & & & & & & & & & & \\
\hline 31 & 18 & 2.6 & 4.81 & 30.4 & 0.158 & 23.1 & 2.9 & 0.73 & $\mathrm{y}$ & & 25.1 & 52 & 25 \\
\hline 32 & 24 & 2.2 & 4.81 & 30.1 & 0.160 & 20.3 & 2.3 & 0.56 & $y$ & & 24.6 & 42 & 2 \\
\hline 33 & 36 & 1.8 & 4.81 & 30.3 & 0.159 & 16.5 & 1.8 & 0.40 & $n$ & 16.5 & 23.4 & 40 & 15 \\
\hline 28 & 8 & \begin{tabular}{l|}
3.2 \\
\end{tabular} & 81 & 20.3 & |0.237 & 54.1 & 4.6 & 1.60 & $y$ & & 46.2 & 60 & 23 \\
\hline 29 & 12 & 2.6 & 4.81 & 20.2 & 0.238 & 45.0 & 3.3 & 1.08 & $y$ & & 45 & 52 & \\
\hline 30 & 16 & 2.2 & 4.81 & 20.1 & 0.239 & 40.1 & 2.0 & 0.75 & $n$ & & 75.9 & 50 & 13 \\
\hline
\end{tabular}

\subsubsection{Four-Stage Turbine, Vane 2 Injection}

Table 4 presents results for injection at the trailing edge of vane 2. Without simultaneous vane 1 reheat, burnout does not occur. With simultaneous vane 1 reheat, burnout occurs, except that $\mathrm{CO}$ emissions are high. There appears to be a narrow optimum for 8 holes of 2.6 $\mathrm{mm}$ hole size. However, even here the hot streak survive until station 11 (rotor 3 ), which is not desirable.

Table 4 - Vane 2 Trailing Edge Reheat, Fuel for 75 C Boost

\begin{tabular}{|c|c|c|c|c|c|c|c|c|c|c|c|c|c|}
\hline Point & $\mathrm{N}$ & $\begin{array}{r}\text { hole size } \\
\mathrm{mm} \\
\end{array}$ & $\begin{array}{r}\text { fuel flow } \\
\mathrm{kg} / \mathrm{s} \\
\end{array}$ & $\begin{array}{l}\text { area } \\
\mathrm{cm} 2 \\
\end{array}$ & $\begin{array}{r}\text { Fuel flux } \\
\mathrm{kg} / \mathrm{s}-\mathrm{mm} 2\end{array}$ & $\begin{array}{r}\text { Flame } \\
\text { length } \\
\mathrm{cm}\end{array}$ & $\begin{array}{r}\text { Flame } \\
\text { width } \\
\mathrm{cm}\end{array}$ & $\begin{array}{r}\text { Flame } \\
\text { r.t. } \\
\text { msec }\end{array}$ & $\begin{array}{r}\text { D Flame } \\
\text { lit? }\end{array}$ & \begin{tabular}{|r|} 
Burnout \\
loc. \\
$\mathrm{cm}$
\end{tabular} & \begin{tabular}{|r|} 
Plume \\
end loc. \\
$\mathrm{cm}$ \\
\end{tabular} & $\begin{array}{l}\text { NOx } \\
\text { ppm }\end{array}$ & $\begin{array}{c}\mathrm{CO} \\
\mathrm{ppm}\end{array}$ \\
\hline \multicolumn{14}{|c|}{ Vane 2 - Half fuel } \\
\hline 39 & 32 & 3.2 & 1.20 & 91.2 & \begin{tabular}{l|l|}
0.013 \\
\end{tabular} & 7.6 & 1.1 & 0.20 & $\mathrm{n}$ & >end & \begin{tabular}{l|l|}
61.0 \\
\end{tabular} & & \\
\hline 42 & 64 & 2.2 & 1.20 & \begin{tabular}{l|}
90.4 \\
\end{tabular} & 0.013 & 5.6 & \begin{tabular}{l|l}
0.7 \\
\end{tabular} & 0.12 & $\mathrm{n}$ & >end & 58.4 & & \\
\hline 38 & 16 & 3.2 & 1.20 & 45.6 & \begin{tabular}{l|}
0.026 \\
\end{tabular} & 11.4 & 1.7 & 0.31 & $\mathrm{n}$ & >end & 63.5 & & \\
\hline 41 & 32 & 2.2 & 1.20 & 45.2 & 0.027 & \begin{tabular}{l|}
8.1 \\
\end{tabular} & 1.1 & 0.19 & $\mathrm{n}$ & >end & 61.0 & & \\
\hline 44 & 64 & 1.6 & 1.20 & 44.9 & 0.027 & 5.8 & \begin{tabular}{l|l|}
0.7 \\
\end{tabular} & 0.12 & $\mathrm{n}$ & >end & \begin{tabular}{|l|l|}
58.4 & \\
\end{tabular} & & \\
\hline 37 & 8 & 3.2 & 1.20 & 22.8 & \begin{tabular}{l|l|}
0.053 \\
\end{tabular} & 18.5 & 2.5 & 0.61 & $\mathrm{n}$ & >end & 81.3 & & \\
\hline 40 & 16 & 2.2 & 1.20 & 22.6 & 0.053 & 13.2 & 1.7 & 0.36 & $\mathrm{n}$ & >end & 76.2 & & \\
\hline 43 & 32 & 1.6 & 1.20 & 22.4 & \begin{tabular}{l|}
0.054 \\
\end{tabular} & 9.4 & 1.1 & 0.22 & $\mathrm{n}$ & >end & 61.0 & & \\
\hline \multicolumn{14}{|c|}{ Vane 2 after Vane 1 - Half fuel } \\
\hline 47 & 32 & 3.2 & 1.20 & 91.2 & 0.013 & 8.6 & 1.2 & 0.24 & $\mathrm{n}$ & 53.3 & 60.7 & 18 & 422 \\
\hline 51 & 64 & 2.2 & 1.20 & 90.4 & 0.013 & 6.1 & 0.8 & 0.15 & $\mathrm{n}$ & 50.8 & 58.2 & 15 & 478 \\
\hline 46 & 16 & 3.2 & 1.20 & 45.6 & 0.026 & 13.0 & 1.9 & 0.38 & $\mathrm{n}$ & 56.4 & 63.0 & 15 & 596 \\
\hline 50 & 32 & 2.2 & 1.20 & 45.2 & 0.027 & 9.1 & 1.2 & 0.23 & $\mathrm{n}$ & 54.1 & 61.2 & 13 & 492 \\
\hline 53 & 64 & 1.6 & 1.20 & 44.9 & \begin{tabular}{|c|}
0.027 \\
\end{tabular} & \begin{tabular}{l|l}
6.6 \\
\end{tabular} & 0.8 & 0.14 & $\mathrm{n}$ & 52.1 & \begin{tabular}{l|l}
58.7 \\
\end{tabular} & \begin{tabular}{l|}
18 \\
\end{tabular} & 508 \\
\hline 45 & 8 & 3.2 & 1.20 & 22.8 & \begin{tabular}{l|}
0.053 \\
\end{tabular} & 20.8 & 2.7 & 0.70 & $\mathrm{n}$ & 62.2 & 81.3 & 17 & 425 \\
\hline 56 & 12 & 2.6 & 1.20 & 22.8 & \begin{tabular}{|l|}
0.053 \\
\end{tabular} & 17.0 & 2.3 & 0.56 & $\mathrm{n}$ & >end & \begin{tabular}{l|}
77.7 \\
\end{tabular} & \begin{tabular}{l|}
17 \\
\end{tabular} & 771 \\
\hline 49 & 16 & 2.2 & 1.20 & 22.6 & 0.053 & 14.7 & 1.9 & 0.45 & $\mathrm{n}$ & 57.9 & 75.4 & 14 & 702 \\
\hline 52 & 32 & 1.6 & 1.20 & \begin{tabular}{l|}
22.4 \\
\end{tabular} & 0.054 & 10.4 & 1.3 & 0.26 & $\mathrm{n}$ & 55.1 & \begin{tabular}{l|}
62.0 \\
\end{tabular} & 20 & 590 \\
\hline 54 & 8 & 2.6 & 1.20 & 15.2 & 0.079 & 25.1 & 2.5 & 0.75 & $\mathrm{n}$ & 74.9 & 96.0 & 15 & 11 \\
\hline 48 & 4 & 3.2 & 1.20 & 11.4 & 0.105 & 47.5 & 3.9 & 1.33 & $\mathrm{n}$ & 95.0 & >end & & \\
\hline 55 & 6 & 2.6 & 1.20 & 11.4 & \begin{tabular}{l|l|}
0.106 \\
\end{tabular} & 38.9 & 3.3 & 1.07 & $\mathrm{n}$ & 81.8 & 136.1 & 12 & 1721 \\
\hline
\end{tabular}




\subsubsection{Five-Stage Turbine, Vane 2 Injection}

A possible design application of in-situ reheat is in the design of a higher efficiency, higher pressure ratio, 5-stage turbine. In this design concept, the second of the five stages is about the same size as the first stage of a 4-stage turbine, and operates at about the same conditions except that the temperature is lower. Therefore, in the 5-stage turbine, vane 2 trailing edge reheat could be used to reheat the gas up to the inlet temperature of the first rotor of the 4-stage engine.

Performance of this reheat concept is projected in Table 5. It is seen that the diffusion flame is never lit, and that in general $\mathrm{CO}$ emissions are high. The temperature here is too low for non-flameholding burnout. There appear to be several narrow windows for low $\mathrm{CO}$ emissions, but these might be hard to attain in design.

Table 5 - Vane 2 Trailing Edge Reheat for a 5-Stage Turbine

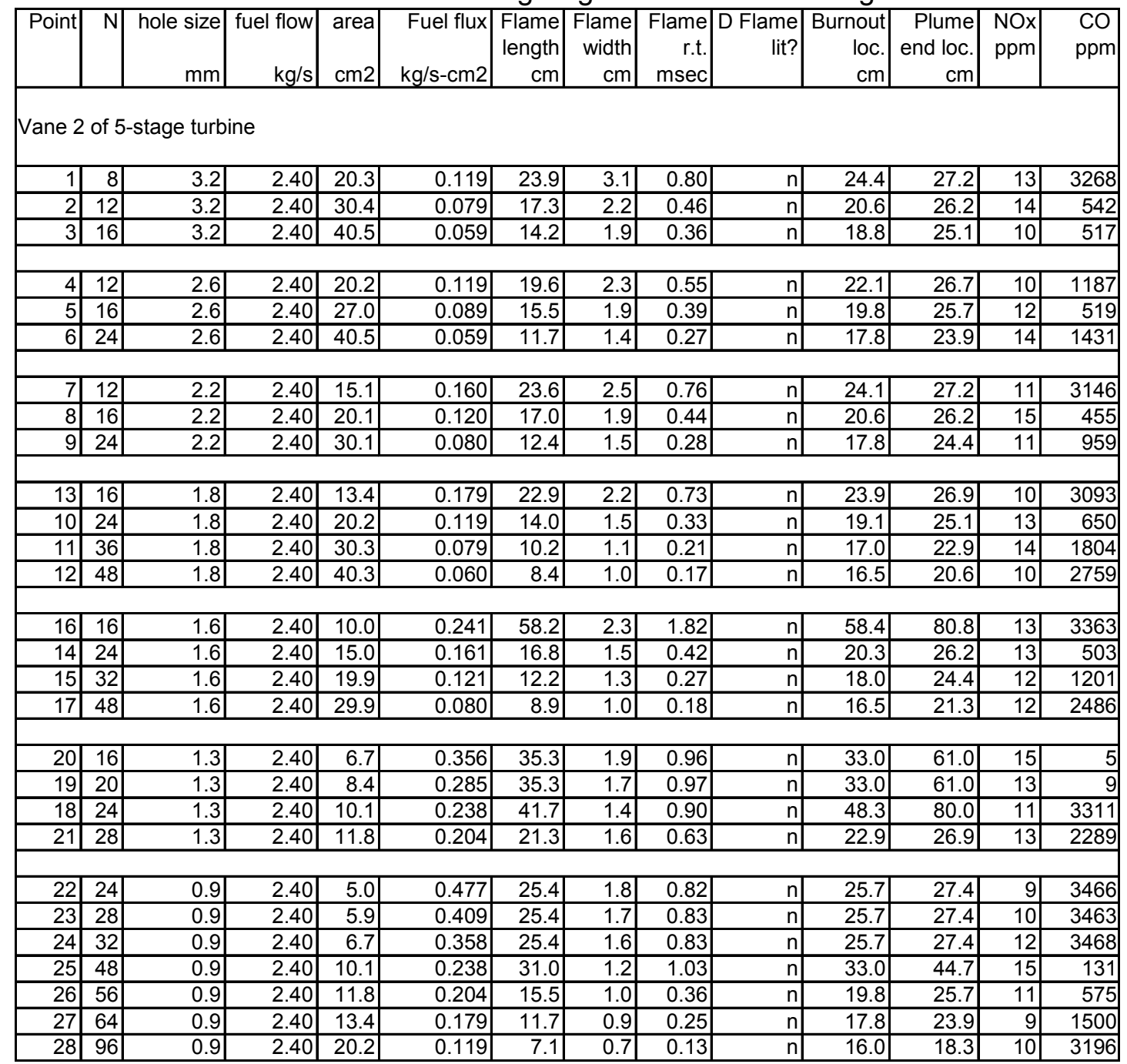




\section{FLAMEHOLDING DESIGN}

\subsection{Modeling Approach}

In cases where injected fuel gas does not burn as a diffusion flame, and does not burn downstream in either a partially mixed (plume) or fully mixed state, a flameholder might be used to stabilize a flame at the injection point. The simplest such design would be to inject the fuel in the wake of a blunt body. In this case the blunt body is a "button" on the trailing edge, with the fuel injection hole at its downstream center. Depending on the fuel flow rate, ambient gas temperature, and button size the resulting "wake flame" may or may not be lit. The purpose of the wake flame is provide a larger stirred reaction zone, and larger residence time, so that burning will occur. At the same time, the wake can be made to provide a leaner burning mixture than a diffusion flame, such that the temperature is lower and NOx is minimized.

While it is not desirable from a turbine blade design point of view to have such objects, even with the upstream edges somehow streamlined and blended with the blade, the concept is examined to see if flame holding has any merit for in situ reheat - if so, then the design can be refined.

Several authors have looked at fuel injection into bluff body wakes. We use the work of Winterfeld [5] who, like other authors, provides dimensions of the recirculation zone, but in addition provides residence times. According to him the volume of the recirculation zone (wake flame) is

where

$$
V=0.66 \cdot(B / d)^{2} \cdot(L / d) D^{3}
$$

$$
\begin{aligned}
& D=\text { diameter of the "button" } \\
& \text { B/d = dimensionless diameter of recirculation zone }=1.2 \text { for a conical shaped, smooth } \\
& \text { approach to the button } \\
& L / d=\text { dimensionless length of the recirculation zone }=2.5 \text { for a flame with this same } \\
& \text { approach design }
\end{aligned}
$$

Also, the residence time of the mixed gases in the wake flame, where the button occupies only a small part of the overall cross-section, is given by

$$
\tau \cdot v / d=20
$$

where

$$
\begin{aligned}
& \tau=\text { residence time } \\
& v=\text { velocity of approach of the main gas stream upstream of the button } \\
& d=\text { button diameter }
\end{aligned}
$$

Given these assumptions, the possible presence of a wake flame is modeled as follows.

1) The calling program (same as for diffusion flame) checks input to determine whether a flameholder is being used and, if so, the diameter of the button. All other parameters are the same as for the non-flameholding design. There is assumed to be one button per hole. 
2) The wake flame residence time and volume are calculated from equations (14) and (15). The volumetric flow of main gas/fuel mixture is calculated from these. Then the fuel flow is subtracted to give the main gas flow entrained.

3) The DFLAME model is called for this mixture and residence time. The residence time is assumed to be divided into a perfectly stirred half, followed by a plug flow half. DFLAME determines if the wake flame is lit and, if so, the products and temperature.

4) The calling program then uses the end of the wake flame as the effective source of a potential diffusion flame. The location and diameter of the effective fuel jet for the diffusion flame are given as the end location of the wake flame and the diameter of the wake flame. The flow rate, composition, and temperature of the effective fuel jet are those of the product of the wake flame.

5) The normal diffusion flame steps (Section 3.1.1, steps 4 to 6) are then executed.

This approach was used to evaluate the in situ reheat flameholding concept. There were no experimental data for validation.

\subsection{Parametric Study Results}

In all of the following cases it is assumed that the main gas entering the turbine has no CO, and has sufficient NOx to give 8 ppmv normalized NOx at the exit of the turbine after mixing with all cooling air and without reheat.

\subsubsection{Four-Stage Turbine, Vane 1 Injection}

Table 6 summarizes the calculations for using a button type flameholder with vane 1 trailing edge reheat. The first line for each "Point" is the same as in Table 2. Subsequent lines for said point then show what happens if the flameholder of the stated diameter is added. Of course, the temperatures around V1TE are high enough that we would like to operate without a flameholder, as shown in several instances in Table 2; but we will examine use of flameholder to see if there is any non-obvious advantage.

Note that for all points in Table 6, and subsequent tables 7 through 10 , the wake mixture is rich, usually very rich as shown by the low adiabatic flame temperature. This means that it is not likely to ignite except when the largest wakes are used, which form mixtures nearest to stoichiometric. Also, the maximum button size shown for each point is limited by getting one button per each of $\mathrm{N}$ holes on each vane; so larger sizes than shown on the tables are not possible.

For point 16, the diffusion flame lights even without a flameholder, so the use of a flameholder has little effect, until the wake flame is lit for the largest holder size, $12.7 \mathrm{~mm}$, at which point the NOx emissions rise. Similarly, for other points in Table 6, the button can cause the diffusion flame to light, or the wake flame to light, or both to light, or neither to light. In each case there is either no significant change in emissions, or an increase in emissions. and the diffusion flame to light, with the same effect on NOx. We conclude that a flameholding design is disadvantageous for the vane 1 trailing edge, which works fine without a flameholder in most cases. Table 7 shows no benefit for higher fuel injection rates.

Another effect seen in Table 6 is for point 27, where a few large injection holes are used. Without a flameholder the flame and plume extend to the end of the turbine, so combustion is 
incomplete. With a flameholder, combustion is pulled back and is completed in the turbine, but NOx emissions are high.

Table 6 - Vane 1 Trailing Edge with Flameholding

\begin{tabular}{|c|c|c|c|c|c|c|c|c|c|c|c|c|}
\hline Point & $\mathrm{N}$ & $\begin{array}{r}\text { hole size } \\
\mathrm{mm} \\
\end{array}$ & $\begin{array}{r}\text { fuel flow } \\
\mathrm{kg} / \mathrm{s} \\
\end{array}$ & $\begin{array}{c}\text { Fuel flux } \\
\mathrm{kg} / \mathrm{s}-\mathrm{cm} 2 \\
\end{array}$ & 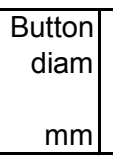 & $\begin{array}{r}\text { Wake } \\
\text { Taf } \\
\mathrm{K} \\
\end{array}$ & \begin{tabular}{r|} 
Wake \\
flame \\
r.t. \\
msec \\
\end{tabular} & $\begin{array}{r}\text { Wake } \\
\text { flame } \\
\text { lit? }\end{array}$ & $\begin{array}{r}\text { Diff } \\
\text { flame } \\
r . t . \\
\text { msec }\end{array}$ & $\begin{array}{r}\text { Diff } \\
\text { flame } \\
\text { lit? }\end{array}$ & $\begin{array}{l}\text { NOx } \\
\text { ppm }\end{array}$ & $\begin{array}{l}\mathrm{CO} \\
\mathrm{ppm}\end{array}$ \\
\hline \multicolumn{13}{|c|}{ Vane 1- Base fuel } \\
\hline \multirow[t]{6}{*}{16} & 12 & 3.2 & 2.40 & 0.079 & & & & & \begin{tabular}{l|l}
0.40 \\
\end{tabular} & $\mathrm{y}$ & 24 & 9 \\
\hline & & & & & 3.8 & 868 & 0.14 & $\mathrm{n}$ & \begin{tabular}{l|l|}
0.52 \\
\end{tabular} & y & 30 & 12 \\
\hline & & & & & 5.1 & 979 & 0.18 & $\mathrm{n}$ & 0.52 & $\mathrm{y}$ & 32 & 9 \\
\hline & & & & & 6.4 & 1061 & 0.23 & $\mathrm{n}$ & 0.51 & $\mathrm{y}$ & 29 & 8 \\
\hline & & & & & 9.7 & 1344 & 0.34 & $\mathrm{n}$ & 0.51 & $\mathrm{y}$ & 32 & 8 \\
\hline & & & & & 12.7 & 1754 & 0.46 & $\mathrm{y}$ & \begin{tabular}{l|l}
0.67 \\
\end{tabular} & $\mathrm{y}$ & 45 & 7 \\
\hline \multirow[t]{4}{*}{18} & 24 & 2.2 & 2.40 & 0.080 & & & & & 0.25 & $\mathrm{n}$ & 16 & 11 \\
\hline & & & & & 3.0 & 917 & 0.11 & $\mathrm{n}$ & 0.32 & $\mathrm{n}$ & 19 & 9 \\
\hline & & & & & 4.6 & 1066 & 0.16 & $\mathrm{n}$ & \begin{tabular}{l|l}
0.31 \\
\end{tabular} & $\mathrm{n}$ & 16 & 11 \\
\hline & & & & & 6.4 & 1259 & 0.23 & $\mathrm{n}$ & 0.31 & $\mathrm{y}$ & 29 & 16 \\
\hline \multirow[t]{3}{*}{21} & 72 & 1.3 & 2.40 & 0.079 & & & & & 0.13 & n & 12 & 97 \\
\hline & & & & & 1.8 & 897 & 0.06 & $\mathrm{n}$ & \begin{tabular}{l|l}
0.16 \\
\end{tabular} & $\mathrm{n}$ & 15 & 72 \\
\hline & & & & & 2.3 & 993 & 0.08 & $\mathrm{n}$ & \begin{tabular}{l|l}
0.16 \\
\end{tabular} & $\mathrm{n}$ & 17 & 114 \\
\hline \multirow[t]{4}{*}{22} & 15 & 2.6 & 2.40 & 0.095 & & & & & 0.35 & $\mathrm{n}$ & 23 & 0 \\
\hline & & & & & 5.1 & 1019 & 0.18 & $\mathrm{n}$ & 0.44 & $y$ & 30 & 8 \\
\hline & & & & & 7.6 & 1202 & 0.27 & $\mathrm{n}$ & \begin{tabular}{l|l|}
0.43 \\
\end{tabular} & y & 29 & 8 \\
\hline & & & & & 10.9 & 1699 & 0.39 & $\mathrm{y}$ & 0.57 & $\mathrm{y}$ & 40 & 8 \\
\hline \multirow[t]{4}{*}{24} & 30 & 1.8 & 2.40 & 0.095 & & & & & 0.22 & $\mathrm{n}$ & 14 & 15 \\
\hline & & & & & 2.5 & 889 & 0.09 & $\mathrm{n}$ & 0.27 & $\mathrm{n}$ & 19 & 11 \\
\hline & & & & & 3.8 & 1041 & 0.14 & $\mathrm{n}$ & \begin{tabular}{l|l|}
0.27 \\
\end{tabular} & $\mathrm{n}$ & \begin{tabular}{l|l}
18 \\
\end{tabular} & 17 \\
\hline & & & & & \begin{tabular}{l|}
5.5 \\
\end{tabular} & 1224 & \begin{tabular}{l|l|}
0.20 \\
\end{tabular} & $\mathrm{n}$ & \begin{tabular}{l|l}
0.27 \\
\end{tabular} & $\mathrm{y}$ & \begin{tabular}{l|l}
20 \\
\end{tabular} & 24 \\
\hline & & & & & & & & & & & & \\
\hline \multirow[t]{4}{*}{4} & 24 & 1.8 & 2.40 & \begin{tabular}{l|l|}
0.119 \\
\end{tabular} & & & & & \begin{tabular}{l|l|}
0.28 \\
\end{tabular} & $\mathrm{n}$ & 14 & 9 \\
\hline & & & & & 3.0 & 917 & 0.11 & $\mathrm{n}$ & |0.31 & $\mathrm{n}$ & 19 & 9 \\
\hline & & & & & 5.1 & 1105 & $\begin{array}{ll}0.18 \\
\end{array}$ & $\mathrm{n}$ & \begin{tabular}{l|}
0.31 \\
\end{tabular} & $\mathrm{y}$ & 21 & 12 \\
\hline & & & & & 6.9 & 1368 & 0.25 & $\mathrm{n}$ & \begin{tabular}{l|l|}
0.32 \\
\end{tabular} & y & 26 & 21 \\
\hline \multirow[t]{3}{*}{7} & 96 & 0.9 & 2.40 & 0.119 & & & & & \begin{tabular}{l|l|}
0.10 \\
\end{tabular} & $\mathrm{n}$ & 20 & 181 \\
\hline & & & & & 1.3 & 843 & 0.05 & $\mathrm{n}$ & \begin{tabular}{l|l|}
0.12 \\
\end{tabular} & $\mathrm{n}$ & 16 & 182 \\
\hline & & & & & \begin{tabular}{l|l|}
1.7 & \\
\end{tabular} & 959 & \begin{tabular}{ll|}
0.06 \\
\end{tabular} & $\mathrm{n}$ & \begin{tabular}{l|l|}
0.12 \\
\end{tabular} & $\mathrm{n}$ & 20 & 217 \\
\hline \multirow[t]{3}{*}{27} & 3 & 2.6 & 2.40 & 0.475 & & & & & 3.49 & $y$ & $>$ past enc & \\
\hline & & & & & 6.4 & 791 & 0.23 & $\mathrm{n}$ & 0.82 & $\mathrm{y}$ & 28 & 6 \\
\hline & & & & & \begin{tabular}{l|l|}
8.9 \\
\end{tabular} & 928 & \begin{tabular}{l|l|}
0.32 \\
\end{tabular} & $\mathrm{n}$ & \begin{tabular}{l|l|}
0.99 \\
\end{tabular} & $\mathrm{y}$ & \begin{tabular}{l|l}
30 & \\
\end{tabular} & 4 \\
\hline \multirow[t]{4}{*}{57} & 72 & 0.9 & 2.40 & 0.159 & & & & & 0.15 & $\mathrm{n}$ & 16 & 43 \\
\hline & & & & & 1.3 & 782 & 0.05 & $\mathrm{n}$ & 0.15 & $\mathrm{n}$ & 15 & 76 \\
\hline & & & & & 1.8 & 921 & \begin{tabular}{l|l|}
0.06 \\
\end{tabular} & $\mathrm{n}$ & \begin{tabular}{l|l|}
0.15 \\
\end{tabular} & $\mathrm{n}$ & 23 & 113 \\
\hline & & & & & 2.3 & 1014 & 0.08 & $\mathrm{n}$ & 0.15 & $\mathrm{n}$ & 15 & 148 \\
\hline \multirow[t]{3}{*}{59} & 54 & 0.9 & 2.40 & 0.212 & & & & & \begin{tabular}{l|}
0.27 \\
\end{tabular} & $\mathrm{n}$ & \begin{tabular}{l|l}
13 \\
\end{tabular} & 9 \\
\hline & & & & & 2.0 & 917 & 0.07 & $\mathrm{n}$ & 0.18 & $\mathrm{n}$ & 17 & 48 \\
\hline & & & & & \begin{tabular}{l|l|}
3.0 \\
\end{tabular} & 1066 & \begin{tabular}{ll|}
0.11 \\
\end{tabular} & $\mathrm{n}$ & \begin{tabular}{l|l|}
0.18 \\
\end{tabular} & $\mathrm{n}$ & 23 & 101 \\
\hline
\end{tabular}


Table 7 - Vane 1 Trailing Edge with Flameholding - Increased Fuel

\begin{tabular}{|c|c|c|c|c|c|c|c|c|c|c|c|c|}
\hline Point & $\mathrm{N}$ & $\begin{array}{r}\text { hole size } \\
\mathrm{mm} \\
\end{array}$ & fuel flow & $\begin{array}{l}\text { Fuel flux } \\
\mathrm{kg} / \mathrm{s}-\mathrm{cm} 2\end{array}$ & 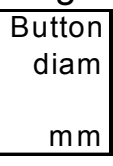 & $\begin{array}{r}\text { Wake } \\
\text { Taf } \\
\text { K } \\
\end{array}$ & \begin{tabular}{r|} 
Wake \\
flame \\
r.t. \\
msec \\
\end{tabular} & $\begin{array}{r}\text { Wake } \\
\text { flame } \\
\text { lit? }\end{array}$ & $\begin{array}{r}\text { Diff } \\
\text { flame } \\
\text { r.t. } \\
\text { msec } \\
\end{array}$ & $\begin{array}{r}\text { Diff } \\
\text { flame } \\
\text { lit? }\end{array}$ & $\begin{array}{l}\text { NOx } \\
\text { ppm }\end{array}$ & $\begin{array}{l}\mathrm{CO} \\
\mathrm{ppm}\end{array}$ \\
\hline \multicolumn{13}{|c|}{ Vane 1 - Double fuel } \\
\hline \multirow[t]{3}{*}{35} & 48 & 1.8 & 4.81 & 0.119 & & & & & 0.28 & $\mathrm{n}$ & 17 & 21 \\
\hline & & & & & 2.5 & 843 & 0.09 & $\mathrm{n}$ & 0.32 & $\mathrm{n}$ & 27 & 21 \\
\hline & & & & & 3.4 & 962 & 0.12 & $\mathrm{n}$ & 0.32 & $\mathrm{n}$ & 25 & 25 \\
\hline & & & & & & & & & & & & \\
\hline \multirow[t]{4}{*}{28} & 8 & 3.2 & 4.81 & 0.237 & & & & & 1.60 & $\mathrm{y}$ & 60 & 23 \\
\hline & & & & & 6.4 & 852 & 0.23 & $\mathrm{n}$ & 1.10 & $\mathrm{y}$ & 58 & 67 \\
\hline & & & & & 12.7 & 1112 & 0.45 & $\mathrm{n}$ & 1.30 & $\mathrm{y}$ & 67 & 37 \\
\hline & & & & & 20.6 & 1662 & 0.74 & $\mathrm{y}$ & 1.70 & $\mathrm{y}$ & 122 & 34 \\
\hline \multirow[t]{3}{*}{30} & 16 & 2.2 & 4.81 & 0.239 & & & & & 0.75 & $\mathrm{n}$ & 50 & 13 \\
\hline & & & & & 3.8 & 782 & 0.14 & $\mathrm{n}$ & 0.78 & $y$ & 58 & 26 \\
\hline & & & & & 7.0 & 1021 & 0.25 & $\mathrm{n}$ & 0.76 & $\mathrm{y}$ & 53 & 22 \\
\hline
\end{tabular}

\subsubsection{Four-Stage Turbine, Vane 2 Injection}

Table 8 (compare top of Table 4) shows that using a relatively large flameholder for vane 2 trailing edge fuel injection enables burnout in some cases not possible without flameholding. However, these cases may have 50 to 100 ppmv CO survival. With Vane 2 injection after Vane 1 injection (Table 9 compared to bottom of Table 4) the flameholder shortens the flame and reduces $\mathrm{CO}$ by an order of magnitude, but it is still about 50 ppmv.

\subsubsection{Five-Stage Turbine, Vane 2 Injection}

Table 10 shows flameholding for vane 2 injection in a high pressure ration 5 -stageturbine, and should be compared to Table 5. It is seen that large diameter buttons enable ignition of wake flames, permitting reasonable operation, with complete burnout but with NOx levels a bit higher than desirable. In cases where the button size is limited by the need to put a large number of holes along a blade, there is no wake ignition and there is poor downstream combustion. 
Table 8 - Vane 2 Trailing Edge with Flameholding

\begin{tabular}{|c|c|c|c|c|c|c|c|c|c|c|c|c|}
\hline Point & $\mathrm{N}$ & $\begin{array}{r}\text { hole size } \\
\mathrm{mm} \\
\end{array}$ & $\begin{array}{r}\text { fuel flow } \\
\mathrm{kg} / \mathrm{s}\end{array}$ & $\begin{array}{c}\text { Fuel flux } \\
\mathrm{kg} / \mathrm{s}-\mathrm{cm} 2 \\
\end{array}$ & $\begin{array}{r}\text { Button } \\
\text { diam } \\
\mathrm{mm} \\
\end{array}$ & $\begin{array}{r}\text { Wake } \\
\text { Taf } \\
\mathrm{K} \\
\end{array}$ & $\begin{array}{r}\text { Wake } \\
\text { flame } \\
\text { r.t. } \\
\text { msec } \\
\end{array}$ & $\begin{array}{r}\text { Wake } \\
\text { flame } \\
\text { lit? }\end{array}$ & $\begin{array}{r}\text { Diff } \\
\text { flame } \\
\text { r.t. } \\
\text { msec }\end{array}$ & $\begin{array}{r}\text { Diff } \\
\text { flame } \\
\text { lit? }\end{array}$ & $\begin{array}{l}\text { NOx } \\
\mathrm{ppm}\end{array}$ & $\begin{array}{l}\mathrm{CO} \\
\mathrm{ppm}\end{array}$ \\
\hline \multicolumn{13}{|c|}{ Vane 2 - Half fuel } \\
\hline \multirow[t]{4}{*}{39} & 32 & 3.2 & 1.20 & \begin{tabular}{l|l|}
0.013 \\
\end{tabular} & & & & & 0.20 & $\mathrm{n}$ & $>$ past end & \\
\hline & & & & & 4.6 & 1057 & 0.17 & $\mathrm{n}$ & 0.23 & $\mathrm{n}$ & $>$ past end & \\
\hline & & & & & 6.1 & 1330 & 0.23 & $\mathrm{n}$ & 0.25 & $\mathrm{n}$ & >past end & \\
\hline & & & & & 8.1 & 1738 & 0.30 & $\mathrm{n}$ & 0.29 & $\mathrm{n}$ & >past end & \\
\hline \multirow[t]{3}{*}{42} & 64 & 2.2 & 1.20 & 0.013 & & & & & 0.12 & $\mathrm{n}$ & >past end & \\
\hline & & & & & 3.0 & 1036 & 0.11 & $\mathrm{n}$ & 0.14 & $\mathrm{n}$ & >past end & \\
\hline & & & & & \begin{tabular}{l|l}
4.1 \\
\end{tabular} & 1251 & 0.15 & $\mathrm{n}$ & 0.15 & $\mathrm{n}$ & >past end & \\
\hline \multirow{4}{*}{38} & 16 & 3.2 & 1.20 & 0.026 & & & & & 0.31 & $n$ & >past end & \\
\hline & & & & & 5.1 & 978 & 0.19 & $\mathrm{n}$ & 0.37 & $\mathrm{n}$ & $>$ past end & \\
\hline & & & & & 10.2 & 1556 & 0.38 & $\mathrm{n}$ & 0.42 & $\mathrm{n}$ & $>$ past end & \\
\hline & & & & & 16.3 & 2161 & 0.61 & y & 0.74 & $\mathrm{y}$ & 14 & 94 \\
\hline \multirow[t]{2}{*}{41} & 32 & 2.2 & 1.20 & 0.027 & & & & & 0.19 & $\mathrm{n}$ & $>$ past end & \\
\hline & & & & & 8.1 & 1738 & 0.30 & $\mathrm{n}$ & 0.29 & $\mathrm{n}$ & >past end & \\
\hline \multirow[t]{3}{*}{44} & 64 & 1.6 & 1.20 & 0.027 & & & & & 0.12 & $\mathrm{n}$ & >past end & \\
\hline & & & & & 3.0 & 1036 & 0.11 & $\mathrm{n}$ & 0.14 & $\mathrm{n}$ & >past end & \\
\hline & & & & & 4.1 & 1251 & 0.15 & $\mathrm{n}$ & 0.15 & $\mathrm{n}$ & >past end & \\
\hline & & & & & & & & & & & & \\
\hline \multirow[t]{5}{*}{37} & 8 & 3.2 & 1.20 & 0.053 & & & & & 0.61 & $\mathrm{n}$ & >past end & \\
\hline & & & & & 6.4 & 936 & 0.24 & $\mathrm{n}$ & 0.67 & $\mathrm{n}$ & >past end & \\
\hline & & & & & 12.7 & 1387 & 0.47 & $\mathrm{n}$ & 0.66 & $y$ & 17 & 54 \\
\hline & & & & & 19.1 & 1941 & 0.71 & $\mathrm{y}$ & 1.08 & $y$ & 14 & 54 \\
\hline & & & & & 25.4 & 2261 & 0.95 & $\mathrm{y}$ & 0.99 & $\mathrm{y}$ & 23 & 77 \\
\hline \multirow[t]{5}{*}{40} & 16 & 2.2 & 1.20 & 0.053 & & & & & 0.36 & $n$ & >past end & \\
\hline & & & & & 5.1 & 978 & 0.19 & $\mathrm{n}$ & 0.37 & $\mathrm{n}$ & $>$ past end & \\
\hline & & & & & 10.2 & 1556 & 0.38 & $\mathrm{n}$ & \begin{tabular}{l|l}
0.42 \\
\end{tabular} & $\mathrm{n}$ & >past end & \\
\hline & & & & & 13.2 & 1913 & 0.49 & $y$ & 0.65 & $y$ & 19 & 71 \\
\hline & & & & & 16.3 & 2161 & 0.61 & y & 0.74 & y & 14 & 94 \\
\hline \multirow[t]{5}{*}{43} & 32 & 1.6 & 1.20 & 0.054 & & & & & 0.22 & $\mathrm{n}$ & $>$ past end & \\
\hline & & & & & 3.0 & 921 & 0.11 & $\mathrm{n}$ & 0.23 & $\mathrm{n}$ & >past end & \\
\hline & & & & & 4.1 & 1016 & 0.15 & $\mathrm{n}$ & \begin{tabular}{l|l}
0.23 \\
\end{tabular} & $\mathrm{n}$ & >past end & \\
\hline & & & & & 6.1 & 1330 & 0.23 & $\mathrm{n}$ & 0.25 & $\mathrm{n}$ & >past end & \\
\hline & & & & & 8.1 & 1738 & 0.30 & $\mathrm{n}$ & 0.29 & $\mathrm{n}$ & >past end & \\
\hline
\end{tabular}


Table 9 - Vane 2 Trailing Edge Injection after Vane 1 Trailing Edge Injection, with Flameholding

\begin{tabular}{|c|c|c|c|c|c|c|c|c|c|c|c|c|}
\hline Point & $\mathrm{N}$ & $\begin{array}{r}\text { hole size } \\
\mathrm{mm} \\
\end{array}$ & $\begin{array}{r}\text { fuel flow } \\
\mathrm{kg} / \mathrm{s}\end{array}$ & $\begin{array}{l}\text { Fuel flux } \\
\mathrm{kg} / \mathrm{s}-\mathrm{cm} 2\end{array}$ & $\begin{array}{r}\text { Button } \\
\text { diam } \\
\text { mm }\end{array}$ & $\begin{array}{r}\text { Wake } \\
\text { Taf } \\
\mathrm{K} \\
\end{array}$ & $\begin{array}{r}\text { Wake } \\
\text { flame } \\
\text { r.t. } \\
\text { msec } \\
\end{array}$ & $\begin{array}{r}\text { Wake } \\
\text { flame } \\
\text { lit? }\end{array}$ & $\begin{array}{r}\text { Diff } \\
\text { flame } \\
r . t . \\
\text { msec } \\
\end{array}$ & $\begin{array}{r}\text { Diff } \\
\text { flame } \\
\text { lit? }\end{array}$ & $\begin{array}{l}\text { NOx } \\
\text { ppm }\end{array}$ & $\begin{array}{l}\mathrm{CO} \\
\mathrm{ppm}\end{array}$ \\
\hline \multicolumn{13}{|c|}{ Vane 2 after Vane 1 - Half fuel } \\
\hline \multirow[t]{4}{*}{47} & 32 & 3.2 & 1.20 & 0.013 & & & & & 0.24 & $\mathrm{n}$ & 18 & 422 \\
\hline & & & & & 4.1 & 1019 & 0.15 & $\mathrm{n}$ & 0.29 & $\mathrm{n}$ & 19 & 182 \\
\hline & & & & & 6.1 & 1324 & 0.22 & $\mathrm{n}$ & 0.29 & $\mathrm{n}$ & 14 & 402 \\
\hline & & & & & 8.1 & 1714 & 0.30 & $\mathrm{n}$ & 0.34 & $y$ & 16 & 91 \\
\hline \multirow[t]{2}{*}{51} & 64 & 2.2 & 1.20 & 0.013 & & & & & 0.15 & $\mathrm{n}$ & 15 & 478 \\
\hline & & & & & 4.1 & 1259 & 0.15 & $\mathrm{n}$ & 0.18 & $\mathrm{n}$ & & \\
\hline \multirow[t]{6}{*}{46} & 16 & 3.2 & 1.20 & 0.026 & & & & & 0.38 & $\mathrm{n}$ & 15 & 596 \\
\hline & & & & & 4.1 & 906 & 0.15 & $\mathrm{n}$ & 0.51 & $\mathrm{n}$ & 12 & 650 \\
\hline & & & & & 8.1 & 1261 & 0.30 & $\mathrm{n}$ & 0.46 & $\mathrm{y}$ & 17 & 43 \\
\hline & & & & & 10.2 & 1561 & 0.37 & $\mathrm{n}$ & 0.49 & $y$ & 18 & 49 \\
\hline & & & & & 12.2 & 1796 & 0.45 & $\mathrm{y}$ & 0.66 & $y$ & 23 & 41 \\
\hline & & & & & 16.3 & 2149 & 0.60 & $\mathrm{y}$ & 0.79 & $\mathrm{y}$ & 20 & 54 \\
\hline \multirow[t]{5}{*}{45} & 8 & 3.2 & 1.20 & 0.053 & & & & & 0.70 & $\mathrm{n}$ & 17 & 425 \\
\hline & & & & & 6.4 & 938 & 0.23 & $\mathrm{n}$ & 0.80 & $\mathrm{y}$ & 19 & 48 \\
\hline & & & & & 12.7 & 1394 & 0.47 & $\mathrm{n}$ & 0.81 & $y$ & 18 & 43 \\
\hline & & & & & 19.1 & 1928 & 0.70 & $\mathrm{y}$ & 1.16 & $\mathrm{y}$ & 21 & 46 \\
\hline & & & & & 25.4 & 2246 & 0.94 & $\mathrm{y}$ & 1.20 & $\mathrm{y}$ & 26 & 49 \\
\hline \multirow[t]{4}{*}{49} & 16 & 2.2 & 1.20 & 0.053 & & & & & 0.45 & $\mathrm{n}$ & 14 & 702 \\
\hline & & & & & 4.1 & 906 & 0.15 & $\mathrm{n}$ & 0.51 & $\mathrm{n}$ & 12 & 650 \\
\hline & & & & & 8.1 & 1261 & 0.30 & $\mathrm{n}$ & 0.46 & $y$ & 17 & 43 \\
\hline & & & & & 12.2 & 1796 & 0.45 & $\mathrm{y}$ & 0.66 & $\mathrm{y}$ & 23 & 41 \\
\hline \multirow[t]{4}{*}{54} & 8 & 2.6 & 1.20 & 0.079 & & & & & 0.75 & $\mathrm{n}$ & 15 & 11 \\
\hline & & & & & 6.4 & 938 & 0.23 & $\mathrm{n}$ & 0.80 & $y$ & 19 & 48 \\
\hline & & & & & 12.7 & 1394 & 0.47 & $\mathrm{n}$ & 0.81 & $y$ & 18 & 43 \\
\hline & & & & & 19.1 & 1928 & 0.70 & $\mathrm{y}$ & 1.16 & $y$ & 21 & 46 \\
\hline
\end{tabular}


Table 10 - Vane 2 Trailing Edge Injection for a 5-Stage Turbine, with Flameholding

\begin{tabular}{|r|r|r|r|r|r|r|r|r|r|r|r|r|}
\hline Point & $\mathrm{N}$ & hole size & fuel flow & Fuel flux & $\begin{array}{r}\text { Button } \\
\text { diam }\end{array}$ & $\begin{array}{r}\text { Wake } \\
\text { Taf }\end{array}$ & $\begin{array}{r}\text { Wake } \\
\text { flame }\end{array}$ & $\begin{array}{r}\text { Wake } \\
\text { flame } \\
\text { r.t. }\end{array}$ & $\begin{array}{r}\text { Diff } \\
\text { flame } \\
\text { lit? }\end{array}$ & $\begin{array}{r}\text { Diff } \\
\text { flame } \\
\text { lit? }\end{array}$ & $\begin{array}{r}\text { NOx } \\
\text { ppm }\end{array}$ & CO \\
& & & & & & & & & \\
& & $\mathrm{mm}$ & $\mathrm{kg} / \mathrm{s}$ & $\mathrm{kg} / \mathrm{s}-\mathrm{cm} 2$ & $\mathrm{~mm}$ & $\mathrm{~K}$ & $\mathrm{msec}$ & & $\mathrm{msec}$ & \\
\hline
\end{tabular}

Vane 2 of 5 -stage turbine

\begin{tabular}{|c|c|c|c|c|c|c|c|c|c|c|c|c|}
\hline 1 & 8 & \begin{tabular}{l|}
3.2 \\
\end{tabular} & 2.40 & 0.119 & & & & & 0.80 & $\mathrm{n}$ & \begin{tabular}{l|l|}
13 \\
\end{tabular} & 3268 \\
\hline & & & & & 5.1 & 866 & 0.19 & $\mathrm{n}$ & 0.82 & $\mathrm{n}$ & 12 & 2612 \\
\hline & & & & & 10.2 & 1112 & 0.39 & $\mathrm{n}$ & 0.70 & $y$ & 19 & 14 \\
\hline & & & & & 15.2 & 1563 & 0.58 & $y$ & 1.03 & y & 28 & 11 \\
\hline & & & & & 20.6 & 1951 & $\begin{array}{l}0.78 \\
\end{array}$ & $y$ & 1.15 & $y$ & 26 & 11 \\
\hline \multirow[t]{4}{*}{2} & 12 & 3.2 & 2.40 & 0.079 & & & & & 0.46 & $\mathrm{n}$ & 14 & 542 \\
\hline & & & & & 5.1 & 942 & 0.19 & $\mathrm{n}$ & 0.54 & $\mathrm{n}$ & 16 & 361 \\
\hline & & & & & 10.2 & 1292 & 0.39 & $\mathrm{n}$ & 0.53 & $\mathrm{n}$ & 11 & 781 \\
\hline & & & & & 13.7 & 1699 & 0.52 & $y$ & 0.77 & $y$ & 37 & 16 \\
\hline \multirow[t]{4}{*}{3} & 16 & 3.2 & 2.40 & 0.059 & & & & & 0.36 & $\mathrm{n}$ & 10 & 517 \\
\hline & & & & & 5.1 & 991 & 0.19 & $\mathrm{n}$ & 0.44 & $\mathrm{n}$ & 11 & 486 \\
\hline & & & & & 7.6 & 1145 & 0.29 & $\mathrm{n}$ & 0.42 & $\mathrm{n}$ & 14 & 1030 \\
\hline & & & & & 10.2 & 1489 & 0.39 & $\mathrm{n}$ & 0.45 & $\mathrm{n}$ & 10 & 2180 \\
\hline \multirow[t]{5}{*}{4} & 12 & 2.6 & 2.40 & 0.119 & & & & & 0.55 & $\mathrm{n}$ & 10 & 1187 \\
\hline & & & & & 5.1 & 942 & 0.19 & $\mathrm{n}$ & 0.54 & $\mathrm{n}$ & 16 & 361 \\
\hline & & & & & 10.2 & 1292 & 0.39 & $\mathrm{n}$ & 0.53 & $\mathrm{n}$ & 11 & 781 \\
\hline & & & & & 13.7 & 1699 & 0.52 & $y$ & 0.77 & $y$ & \begin{tabular}{l|l|}
37 & \\
\end{tabular} & 16 \\
\hline & & & & & & & & & & & & \\
\hline \multirow[t]{4}{*}{5} & 16 & 2.6 & 2.40 & 0.089 & & & & & 0.39 & $\mathrm{n}$ & 12 & 519 \\
\hline & & & & & 5.1 & 991 & 0.19 & $\mathrm{n}$ & 0.44 & $\mathrm{n}$ & 11 & 486 \\
\hline & & & & & 7.6 & 1145 & 0.29 & $\mathrm{n}$ & 0.42 & $\mathrm{n}$ & 14 & 1029 \\
\hline & & & & & 10.2 & 1489 & 0.39 & $\mathrm{n}$ & 0.46 & $\mathrm{n}$ & 10 & 2180 \\
\hline & & & & & & & & & & & & \\
\hline \multirow[t]{4}{*}{7} & 12 & 2.2 & 2.40 & 0.160 & & & & & 0.76 & $\mathrm{n}$ & 11 & 3146 \\
\hline & & & & & 5.1 & 942 & 0.19 & $\mathrm{n}$ & 0.54 & $\mathrm{n}$ & 16 & 361 \\
\hline & & & & & 10.2 & 1292 & 0.39 & $\mathrm{n}$ & 0.53 & $\mathrm{n}$ & 11 & 781 \\
\hline & & & & & 13.7 & 1699 & 0.52 & $y$ & 0.77 & $y$ & 37 & 16 \\
\hline
\end{tabular}

\begin{tabular}{|r|r|r|r|r|r|r|r|r|r|r|r|r|}
\hline 13 & 16 & 1.8 & 2.40 & 0.179 & & & & & 0.73 & $\mathrm{n}$ & 10 & 3093 \\
\hline & & & & & 5.1 & 991 & 0.19 & $\mathrm{n}$ & 0.44 & $\mathrm{n}$ & 11 & 486 \\
\hline & & & & & 7.6 & 1145 & 0.29 & $\mathrm{n}$ & 0.42 & $\mathrm{n}$ & 14 & 1029 \\
\hline & & & & & 10.2 & 1489 & 0.39 & $\mathrm{n}$ & 0.45 & $\mathrm{n}$ & 10 & 2180 \\
\hline
\end{tabular}

\begin{tabular}{|r|r|r|r|r|r|r|r|r|r|r|r|r|}
\hline 20 & 16 & 1.3 & 2.40 & 0.356 & & & & & 0.96 & $\mathrm{n}$ & 15 & 5 \\
\hline & & & & & 5.1 & 991 & 0.19 & $\mathrm{n}$ & 0.44 & $\mathrm{n}$ & 11 & 486 \\
\hline & & & & & 7.6 & 1145 & 0.29 & $\mathrm{n}$ & 0.42 & $\mathrm{n}$ & 14 & 1029 \\
\hline & & & & & 10.2 & 1489 & 0.39 & $\mathrm{n}$ & 0.45 & $\mathrm{n}$ & 10 & 2180 \\
\hline
\end{tabular}

\begin{tabular}{|r|r|r|r|r|r|r|r|r|r|r|r|r|}
\hline 22 & 24 & 0.9 & 2.40 & 0.477 & & & & & 0.82 & $\mathrm{n}$ & 9 & 3466 \\
\hline & & & & & 2.5 & 808 & 0.10 & $\mathrm{n}$ & 0.34 & $\mathrm{n}$ & 10 & 810 \\
\hline & & & & & 5.1 & 1058 & 0.19 & $\mathrm{n}$ & 0.32 & $\mathrm{n}$ & 10 & 1819 \\
\hline & & & & & 6.9 & 1234 & 0.26 & $\mathrm{n}$ & 0.32 & $\mathrm{n}$ & 10 & 2736 \\
\hline 24 & 32 & 0.9 & 2.40 & 0.358 & & & & & 0.83 & $\mathrm{n}$ & 12 & 3468 \\
\hline & & & & 2.5 & 866 & 0.10 & $\mathrm{n}$ & 0.27 & $\mathrm{n}$ & 15 & 1605 \\
\hline & & & & & 5.1 & 1112 & 0.19 & $\mathrm{n}$ & 0.26 & $\mathrm{n}$ & 10 & 2934 \\
\hline 25 & 48 & 0.9 & 2.40 & 0.238 & & & & & 1.03 & $\mathrm{n}$ & 15 & 131 \\
\hline & & & & & 1.8 & 806 & 0.07 & $\mathrm{n}$ & 0.21 & $\mathrm{n}$ & 11 & 2302 \\
\hline & & & & & 2.5 & 942 & 0.10 & $\mathrm{n}$ & 0.21 & $\mathrm{n}$ & 13 & 2734 \\
\hline & & & & & 3.3 & 1031 & 0.13 & $\mathrm{n}$ & 0.20 & $\mathrm{n}$ & 12 & 3188 \\
\hline
\end{tabular}




\section{CONCLUSIONS}

\section{Conventional Four-Stage Turbine}

Reheat fuel addition via the vane 1 trailing edge results in burnout of fuel, with resulting increased power output and, for combined cycle operation, increased cycle efficiency.

Vane 1 trailing edge reheat should be done without a flameholder. Such reheat should have an optimum hole size - small enough to prevent diffusion flame formation , but not so small as to allow insufficient high temperature residence time for $\mathrm{CO}$ burnout. Both NOx and $\mathrm{CO}$ emissions are increased by about 10 ppmv with an optimized design

Without the use of a flameholder, reheat fuel added at the vane 2 trailing edge will not burn, unless it is done after vane 1 reheat to turbine inlet temperature, in which case there will be high ( 500 ppmv) CO emissions.

With a flameholder, reheat fuel added at vane 2 can be made to burn with or without vane 1 reheat, but NOx will increase by about 10 ppmv, and CO by about 40 to 50 ppmv.

High pressure ratio five-stage turbine

Reheat fuel injected without a flameholder at the vane 2 (same size and conditions, except temperature, as vane 1 of a 4-stage engine) will burn, but with high $\mathrm{CO}$.

With a flameholder, NOx and CO increases can be kept at about 20 and 10 ppmv respectively. 


\section{REFERENCES}

1. E.V. Carelli, R.D. Holm, T.E. Lippert, and D.M. Bachovchin, Reheat Combustor for Gas Combustion Turbine, U.S. Patent 6,619,026, Siemens Westinghouse Power Corporation, September 16, 2003.

2. W. R. Hawthorne, D.S. Weddell, and H.C. Hottel, "Mixing and Combustion in Turbulent Gas Jets." Third Symposium on Combustion, Flame and Explosion Phenomena. Williams and Wilkins Company, Baltimore, 1949. pp. 267-288.

3. K. Wohl, C. Gazley, and N. Kapp, "Diffusion Flames." Third Symposium on Combustion, Flame and Explosion Phenomena. Williams and Wilkins Company, Baltimore, 1949. pp. 288-299.

4. S.R. Turns, An Introduction to Combustion, Concepts and Applications. McGraw-Hill, New York, 2000. p. 443.

5. G. Winterfeld, "On Processes of Turbulent Exchange Behind Flame Holders." Tenth Symposium (International) on Combustion. The Combustion Institute, Pittsburgh, 1965. pp. 1265-1275. 